\title{
Tools tell tales - climate trends changing threads in the prehistoric Pannonian Plain
}

\author{
Ana Grabundžija ', Emmanuele Russo ${ }^{2}$ \\ 1 Institut für Prähistorische Archäologie, Freie Universität Berlin, Berlin, DE \\ ana.grabundzija@fu-berlin.de \\ 2 Institut für Meteorologie, Freie Universität Berlin, Berlin, DE \\ emmanuele.russo@met.fu-berlin.de
}

\begin{abstract}
This study of prehistoric textile production on the Pannonian Plain is based on indirect evidence dated to the period between the $5^{\text {th }}$ and $2^{\text {nd }}$ millennium $B C$; the study of technological trends and changes that occurred in manufacturing traditions concentrates on fibre processing and production. The functionality analysis of spindle-whorls served as a basis for comparing textile production trends with the results of the climate change model. Climatic changes in the area were simulated by means of a moderate-resolution Global Circulation Model (GCM). The simulation covered the mid-to-late Holocene, from 7000 years BP to the pre-industrial period.
\end{abstract}

IZVLEČEK - Predstavljamo študijo izdelave tkanin v prazgodovini na območju Panonske nižine, ki temelji na posrednih dokazih, ki datirajo v čas 5. in 2. tisočletja pr. n. št.; pri študiju tehnoloških trendov in sprememb, ki so se zgodile v tradicijah izdelave tkanin, se osredotočamo predvsem na procesiranje in izdelavo vlaken. Analiza funkcionalnosti predilnih vretenc nam je služila za osnovno primerjavo med proizvodnjo tkanin in rezultati modela klimatskih sprememb. Klimatske spremembe na tem območju smo simulirali s pomočjo svetovnega modela cirkulacije (ang. GCM) pri srednii resoluciji. Simulacija pokriva čas med srednjim in poznim holocenom, torej od 7000 let pred sedanjostjo do časa pred industrijsko revolucijo.

KEY WORDS - textile production; spindle-whorls; functional analysis; climate forcing; climate modelling

\section{Introduction}

\section{Reconstructing the resources}

Textile fibres can be roughly divided into two main categories, vegetal and animal. At least according to the textile evidence from both Europe (Barber 1991; Rast-Eicher 2005; Médard 2006; 2012) and the Near East (Schick 1988; Alfaro 2002; Burnham 1964; Helbaek 1963) flax (Linum usitatissimum L.) and tree basts were the most frequent sources of textile fibre during the Neolithic period. Although most of the direct findings suggest that the early raw materials used in textile production were mainly of vegetal origin, their preponderance should be considered with caution. Despite the fact that animal fibres are made of protein and therefore are more resistant to decay than vegetal ones, which are composed of cellulose, one should keep in mind that linen preserves better in alkaline conditions, while animal fibres such as wool require acidic environments for preservation (Cybulska, Maik 2007). The fact that they are not found in the contexts investigated might not account for a genuine absence, but rather for the fact that the conditions for preservation were not met.

\section{From the plant}

The wetland settlements of the Alpine region facilitated the investigation of fibre from the flax plant (Linum usitatissimum) and its use in textile production, revealing details of both the plant's development and its dynamics. However, since animal fibres cannot survive in the alkaline soils of circumAlpine dwellings, the possibility of wool use in these rich contexts remains elusive. Flax has been defined 
as one of the 'founder crops' that started agriculture in the Near East (Zohary 1996). Its early and simultaneous use for linen fibre production already in the $8^{\text {th }}$ millennium BC has been attested by textile remains from Nahal Hemar cave in Israel (Schick 1988.31). In Central Europe, linseed specimens from the Jevišovice site at Hundssteig (3100-3010 cal BC) in Lower (eastern) Austria were incidentally found within a row of loom weights (evidence of the oldest in situ weaving loom in Austria. Although there is certainly a long way to go between seed-bearing flax plants and the fibres woven on a loom, this coincidence might well point to the use of flax in textile production (Kohler-Schneider, Cannepele 2009. 67). The earliest surviving linen cords from the circum-Alpine area of Europe attest to its use for textiles in the $4^{\text {th }}$ millennium (Barber 1991.11-15; Médard 2012.386-9; Rast-Eicher 2005.118-20), although the earliest flax seeds in the same area predate the textile finds by almost two millennia.

However, the importance of flax in Eneolithic contexts within the investigated area of South East Europe has also been well documented in more recent reports (Reed 2016). In several studies based on differences in linseed sizes, archaeobotanists have made an effort to clarify the dynamics and patterns of its exploitation (Maier, Schlichtherle 2011; Herbig, Maier 2011). Since it is possible to distinguish between domestic and wild flax seeds (Linum bien$n e$ ), mainly on the basis of features such as seed size (Herbig, Maier 2011; Zohary et al. 2012.101), a similar methodological principle is used to distinguish between the two different varieties of domesticated flax.

Ancient Near Eastern seeds have a length of approx. 4.0 to $4.7 \mathrm{~mm}$ and a width of approx. 2.3 to $2.7 \mathrm{~mm}$, their size remaining unchanged from $5000 \mathrm{BC}$ to 1800 BC (Helbaek 1959.109, Tab. 1). Interestingly, in Central Europe, flax seems to have split into two varieties at an early stage, one with the large seeds used for linseed oil, and another with smaller seeds specialised for making textile fibres.

An extensive study of $4^{\text {th }}$ and $3^{\text {rd }}$ millennium waterlogged flax seeds from a series of wetland settlements in the Alpine region revealed that in the early phase (4000-3700 BC) seeds were significantly larger in comparison to samples from the ensuing periods (Herbig, Maier 2011.529). This difference in size cannot be correlated with natural or climatic variations and, according to the research, two flax varieties may be considered as possible proof of fibre specialisation. In the early phase, a flax type with larger seeds was cultivated for both oil and fibre production, similarly to the Near East (Maier, Schlichtherle 2011.571). At the same time, already in the middle of the $4^{\text {th }}$ millennium BC (around 3400-3300 BC) a small seed fibre type appeared, which was introduced and cultivated to fit the needs of textile production (Herbig, Maier 2011.529).

The effects of osmotic stress on long fibre flax (Chemicosova 2006; Dash et al. 2014) and its preference for colder and wetter conditions could offer an explanation as to why this new fibre variety of improved length and quality became the primary resource in Europe. Indeed, a central European 'flax-boom' ( $\mathrm{Her}$ big, Maier 2011.531-532; Maier, Schlichtherle 2011. 571) occurred at the end of the $4^{\text {th }}$ millennium BC, when textile production intensified.

Spindle-whorls, spindles, loom weights, and finished fragments of netting and fabric allowed for the reconstruction of textile techniques throughout the wetland settlements. Well-preserved layers like those at Arbon-Bleiche 3 and Pfyn-Breitenloo contain the remains of flax processing, which provided valuable information on its preparation and handling. There is sufficient evidence to show that certain villages focused on growing it and processing the fibres (Schlichtherle 2009). Furthermore, the spatial distribution of textile tools within settlements points to the organisation and specialisation of textile work (Maier 2001; Lauzinger, Rast-Eicher 2011.539540). Archaeological and botanical evidence suggest that in addition to the division of labour, certain socioeconomic differences developed whereby goods and economic factors, including flax, were not available to the same extent to all inhabitants (Schlichtherle et al. 2010).

\section{To the animal}

Although the intensified use of animal fibres, namely wool, in textile production, was initially discussed in the context of Sherratt's model (Sherratt 1981), new evidence for milk consumption (Evershed et al. 2008; Bartosiewicz 2007; Craig et al. 2005; Vigne, Helmer 2007) and animal traction (Fabis 2005; Isaakidou 2006; Johannsen 2005) does not support a big time lapse between the initial domestication, focused mainly on meat consumption, and the later use of secondary animal products. No such arguments for the early use of wool have been established so far, since the first woollen textiles are exceptionally rare and appear only from the $4^{\text {th }}$ millennium BC (Rast-Eicher 2014; Shishlina et al. 2003). Further- 
more, linguistic research suggests a common root for the word 'wool' in Indo-European languages, pointing out that the notion of its soft and spinnable characteristics appeared prior to its departure from west-central Asia around 4000 BC (Barber 1991; Chantraine 2009).

Some attempts to place the beginnings of wool use earlier (Rooijakkers 2012) focus primarily on the Near East. New zooarchaeological investigations of sheep husbandry in Northern Mesopotamia (Vila, Helmer 2014) point to fleece exploitation shortly after initial domestication (around $6500 \mathrm{BC}$ ), suggesting that several breeds were involved in the selection process. Thus multi-origins and trade are considered important factors for the cross-breeding process.

Although the first use of wool was suggested to be parenthetical in the context of fibre production and processing, at least as far as spinning is concerned, it does account for the early knowledge both of the resource and its properties. It is thus considered plausible that sheep fleece developed new desired properties gradually (Rast-Eicher, Bender Jørgensen 2013), as a cumulative result of animal selection, involving out-breeding and cross-breeding practices by shepherds. Already developed and established Mesopotamian wool economies in the $3^{\text {rd }}$ millennium BC, known from the numerous cuneiform sources (Charvát 2011) raise the argument that wool's first appearance should be dated much earlier.

An analysis of textile tools from Arslantepe (Laurito et al. 2014) proposed household wool spinning already in the $4^{\text {th }}$ millennium BC, and ethnological research in Greece showed that unspecialised herding can, and did, account for an ample amount of spun thread (Rokou 1994). In addition, both 'Neolithic' and 'Bronze Age' wool types occur in Iron Age contexts. Sheepskins and textiles from Hallstatt in Austria (dated to the 1st millennium BC) show a range of fleece qualities, with a selection of finer wool for weaving (Ryder 1990a; 1990b; 1992). This direct evidence confirms that the development from 'hair' to coarse wool and finally to fine wool in sheep was successive. Consequently, a definition of a sin- gle temporal horizon for the introduction of woolly sheep can be considered unconvincing (Halstead, Isaakidou 2011). Considering that multiple genes account for fleece development (Ryder 1982), Paul Halstead and Valasia Isaakidou proposed that the better fleece qualities might have been selected unintentionally and on diverse occasions (Halstead, Isaakidou 2011. 67).

Moreover, an important argument that additionally supports the idea of the multiple origin of the desired traits was a consequence of the dynamic gene flow - rather than of developed wool economies focused on increased production - is based on the fact that the better qualities of wool, regarding its finesse, are often found in places and periods remote from those interpreted as more specialised and established 1 .

\section{And 'back to the roots'}

The definite separation of farming and foraging has been fairly criticised, and it is plausible that both strategies were practiced simultaneously (Cummings, Harris 2011). The use of foraged plant fibres before, during and beyond the Neolithic is supported by the substantial amount of direct evidence attesting to the common use of indigenous plants, including reeds, grasses and bast fibres from trees (Harris 2014). The best examples from the Pannonian Plain region were found at the Ljubljansko Barje dwellings in Slovenia, with preserved fibres of the grass family (Poaceae) (Pajagič-Bregar et al. 2009) and leaf fibres of lesser bulrush (Typha angustifolia) (Greif 1997.41). Nonetheless, the result of the plant macro remains study of the late $4^{\text {th }}$ millennium Stare Gmajne lakeshore settlement at Ljubljansko barje, should be mentioned, since they revealed that, besides poppy (Papaver somniferum), flax was the highest represented oil plant, which could also have been used for its fibres (Tolar, Velušček 2009; Tolar et al. 2010).

Fabienne Médard concluded that, overall, there are more preserved cords, threads and cloth made from tree bast fibres than those made from flax (Médard 2010.57). She noticed that tree bast fibres (predominantly lime) were used mainly for twined cloth,

\footnotetext{
1 Commenting on Bronze Age wool quality, Michael Ryder compared contemporary Scandinavian and Egyptian produce: "The wool in North Europe was naturally brown, while that in Egypt was white. Surprisingly, however, the Egyptian wool was coarser. This theme of finer wool in more primitive areas, or in earlier periods, is repeated throughout subsequent history" (Ryder 1974.110). Subsequently, this was explained by experts (Rast-Eicher, Bender Jørgensen 2013) as indeed a finer wool quality from 'Nordic' sheep (genetically different from central European and Near Eastern sheep breeds). The Bronze Age 'Nordic' type wool of superior fibre quality to that of contemporary Egyptian production thus provoked a revaluation of the 'improvement through intensification' principle.
} 
whereas flax was used mainly for woven textiles. (Médard 2012.368). This led to the conclusion that most of the tree bast fibres from the Neolithic lake dwellings in Switzerland were spun without a spindle, a technique characteristic especially of spinning long vegetal fibres (Médard 2006.99-102).

The use of both early wool and flax for textiles could be considered in this category. Collected wool tufts and wild flax fibres were probably competitive with the aforementioned plant resources, along with other materials, such as frequently disregarded goat hair (Frangipane et al. 2009). Wild flax fibres were identified in a series of Upper Paleolithic layers at Dzudzuana Cave in Georgia (Kvavadze et al. 2009), indicating that prehistoric hunter-gatherers were already using its fibre to make thread. There was certainly a substantial time lapse in sequential adaptations of fibre use before it become a primary resource for textile production.

Finally, if considered in a wide-scale process that involved gradual modifications and a refinement of practices, it is extremely difficult to decide when and where these secondary products were first recognised and exploited. Although Hans Helbæk suggested that flax was initially used for its seeds and then for its fibre (Helbaek 1959.104; McCorriston 1997), linen evidence is direct proof of its early use for textiles. Preserved textiles confirm that flax was used for its fibre already in the Early Neolithic in the southern Levant (Schick 1988.31).

Alternatively, the quality of early wool could have been controlled to a certain degree through fibre preparation. Sampling and manual sorting of fleeces and tufts could have resolved its hairiness and coarseness, resulting in a selection of spinnable material. This selection practice has been demonstrated with an analysis of Bronze Age skins and textiles from Hallstatt (Rast-Eicher, Bender Jørgensen 2013), revealing how a skilled wool-sorter could identify and categorise a range of wool qualities even with a flock of highly mixed sheep.

Due to gradual specialisation and the secondary product character ascribed to these fibres, it is extremely difficult to investigate the origin of their use and dynamics of their development. On the other hand, following their importance and representation in textile production, it is to some degree possible to determine when, where and why they became a primary resource, as their intensified exploitation was more culturally and environmentally dependent.

\section{Theory and time}

Apart from investigating the biological origins and developments of both wool and flax fibres, social and technological changes connected to their intensified exploitation could be approached through cultural historical narratives and theoretical frameworks. The economies of prehistoric communities across the Pannonian Plain would alter with specialisation in either of the resources, transforming fibre material into a commercial good, possibly involved in export and exchange. Both strategies, if intensified, would imply an increased anthropogenic factor. Maintaining large herds calls for opening the primeval forest vegetation in parts of Europe, where forest cover is not limited by climatic factors. The high water and high-quality agricultural land requirements of flax suggest direct competition with food crops. Thus, the benefits of developing traditional technologies and production as sub-branches of the fragile and not fully formed economies of the period seem even more reasonable.

The processual archaeology approach would argue that this next step was determined by a successful cultural adaptation to climatic and environmental conditions (Binford 1968), while the opposing postprocessual approach would focus on explaining all changes in the past as a result of human agency (Hodder 1980). Regardless of the approach, the fact remains that developments of the technological aspect were the main determinant of 'success'.

Andrew Sherratt assembled different strands of evidence from archaeology and zooarchaeology into a consolidated model of the Secondary Products Revolution (Sherratt 1981). By suggesting that the main by-product of domesticates (traction, riding, milk and wool) occurred simultaneously, first in a narrow time span in the $4^{\text {th }}$ millennium $\mathrm{BC}$, he conceptualised them as economic achievements that developed several millennia after primary, meat-focused consumption. In this model, the main commodity, namely meat, was the objective of Neolithic herders, against the full range of exploitation, an achievement of the Eneolithic. Consequently, the model addressed the secondary products' potential for cultural evolution and social complexity in the transition from the $4^{\text {th }}$ to the $3^{\text {rd }}$ millennium BC. Interestingly, it is not the main postulate of the theory which is criticised, but the contemporaneous occurrence or intensification of different types of exploitation (Vorsteen 1996; Halstead, Isaakidou 2011). One of the biggest supporters of Sherratt's model, Haskel Greenfield, argued for a revision of the con- 
temporaneity of its parts (Greenfield 2005), underlining the importance of intensification in scale, rather than origin of use. The initial critique of the model contributed to further questions on causality: were these 'innovations' a cause or a consequence of social and economic developments, did they influence each other, and finally, how?

The economic importance of secondary products, even if known for a long time, as proved in the case of milk (Evershed et al. 2008; Bartosiewicz 2007; Craig et al. 2005; Vigne, Helmer 2007), increases during the $4^{\text {th }}$ millennium $\mathrm{BC}$, which further shaped our research objectives. The 'competition of fibres' found its place in the paradigm due to the contemporaneity of the specialisation of both resources and the influence on economic factors that accompany their intensified use.

The wide time frame of our investigation, which encompasses two millennia, gave us the opportunity to pattern technological trends and changes on a large scale, rather than addressing culture-specific questions and particular inter-site dynamics. The focus on $4^{\text {th }}$ and $3^{\text {rd }}$ millennium $\mathrm{BC}$ textile production in the Pannonian Plain placed the research within the context of three periods: the Middle Eneolithic, Late Eneolithic and Early Bronze Age. The transformation from Middle to Late Eneolithic and from Late Eneolithic to Early Bronze Age societies in the Pannonian Plain from the final $5^{\text {th }}$ to the ending of the $3^{\text {rd }}$ millennium $\mathrm{BC}$, and the role of local and exogenous influences, remain controversial. Further, all three periods are characterised by a number of partly overlapping 'cultures' whose definition is based primarily on pottery inventories and burial rites, so they do not necessarily represent social or economic communities. The 'Chronological framework for the Copper Age cultures of the Carpathian Basin and neighbouring territories' outlined by Pál Raczky (1995.60, Fig. 1) was chosen as the basis for the periodisation of investigated textile tool samples.

The chronological division we used placed spindlewhorl samples from the $1^{\text {st }}$ half of the $4^{\text {th }}$ millennium BC in the Middle Eneolithic and samples from the $2^{\text {nd }}$ half of the $4^{\text {th }}$ and the very beginning of the $3^{\text {rd }}$ millennium in the Late Eneolithic assemblage. Samples from the advanced $3^{\text {rd }}$ millennium contexts thus entered the Early Bronze Age assemblage. The classification of the investigated cultural-historical groups within these three periods remains arbitrary, especially due to the transitional character ${ }^{2}$ of the particular 'cultures'.

\section{Changing threads}

In the process of hand spinning, the spinner continuously rotates the spindle and the spun yarn attached to it. As the tool rotates, the hands are used to draft the prepared fibres, while the weight of the tool pulls them, and its rotation twists them into a yarn. Tension and speed are the two main factors affecting the transformation from fibre to yarn. Smoother and shorter fibres call for a shorter, lighter draft and more twist to enter the fibres fast enough, while on the other hand, coarser and longer fibres allow for longer and heavier down-pull and less twist without causing a break.

As textile tools for fabricating yarn, spindle-whorls are the most commonly preserved evidence of fibre processing and production practices found in prehistoric contexts. The same proved to be the case with the sites studied in regions of South East and East Central Europe. Fortunately, they are also the most efficacious of textile tools for studying the differences of fibres. It has been widely accepted within the respective field of textile archaeology that the morphological features of the spindle-whorl relate to its functionality. A good number of reports from experimental archaeology have supported this dependency (Grömer 2005; Mårtensson et al. 2006; Verhecken 2010). Nevertheless, the real impact and conditioning of these determinants continue to be questioned and investigated (Kania 2015; Laurito et al. 2014).

As mentioned above, both whorl size and weight account for the rotational properties, while determining the tool's moment of inertia. Perforation diameter and position are two other features that have a significant influence on rotation, later also accoun-

\footnotetext{
2 Despite its integration with the Boleráz group (Stadler et al. 2001.543) and mainly due to its transitional character (Horváth 2001. 83), typological fusion with Lasinja and Furchenstich (Horváth 2009.105), its stylistic affiliation with the 'stab and drag' or 'Furchenstich' decoration complex (Kalicz 2001) and absolute dates that cluster between 3700 and 3500 BC (Horváth 2009.104), the Proto- Boleráz sample recorded from the Abony site was placed within the Middle Eneolithic assemblage together with Lasinja and Furchenstich spindle-whorls. The Vučedol sample recorded from the Gomolava and Slavča-Nova Gradiška sites was placed within the Early Bronze Age assemblage together with Somogyvár-Vinkovci spindle-whorls. Mainly because the big sample recorded from

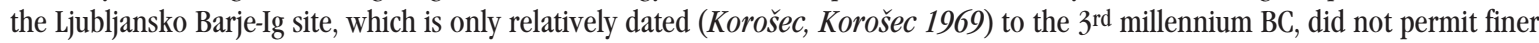
classification according to the particular cultural-historically defined phases.
} 
ting for the whorl's stability during the process. Perforation is to some extent indicative of the spindle on which the whorl was used, thus its dimensions and properties have to be considered, since they also influence rotation.

In the context of the proposed functionality, the moment of inertia and weight of the whorl are given the central role, mainly because they are connected with both the raw material (Verhecken 2010) and the properties of the spun thread (Bohnsack 1981; Crewe 1998). It is generally accepted that lighter weights would be preferred for thinner and lighter threads and heavier for thicker and heavier yarns (Andersson 2015.47). This quality standard is thus taken as the parameter which has the most influence on the end products and their characteristics. The fact that the fibre flax plant would have provided fairly long fibres, especially compared with the much shorter length of wool expected for the early woolly sheep, is the main reason this distinction of raw materials resonated in the dichotomy between spindle-whorl types, with an emphasised contrast between big and heavy and small and light categories.

\section{Climate trends}

In recent decades, the media have taken a great interest in future climate change and its possible impact on society. Adaptation and mitigation policies have become main discussion topics in scientific research. Analyses of past events are often referred to for predictions of future developments, so archaeological and historical data substantially contribute to our understanding of the effects of climate change and its influence on culture and society. Most importantly, the way civilisation reacted or adapted to different environmental conditions in the past could give us vital information on how to respond to the effects of renewed climate stress (Riede 2014).

In order to interpret altering technologies by distinctions between fibres and their reliance on cultural and environmental contexts, our research analysed Eneolithic and Early Bronze Age textile tools in the light of the results of a climate simulation for the period of interest. This comparison of the two sets of data revealed that climate changes might have significantly influenced the observed dynamics of pro- duction traditions. Thus, our approach is a valuable interdisciplinary case study that incorporates bi-univocal examples of the suitability of archaeological analysis, firstly, regarding its use as a comparison data frame for climate modelling results and, secondly, for evaluating the effects of past climate change on culture, particularly innovation and technology.

The results of climate model simulations are particularly suitable for analysing cultural and technological dynamics, since they reveal trends which can explain certain continuities, as well as changes at a higher temporal resolution. This means they enable a wider understanding of the climate's impact on prehistoric societies, since their coverage builds an environmental context for the study of both adaptation processes and their consequences.

\section{Materials and methods}

\section{Scope of the study}

In order to avoid the absence of contextual data and uncertainties regarding 'cultural' and chronological assignments, the choice and collection of material used in this research focused as much as possible on recent excavations, with the exception of several sites ${ }^{3}$. A textile tool database was created that comprises spindle-whorls from over 20 archaeological sites ${ }^{4}$, which gave a presentable transect from the northern slopes of the Central Balkan Mountains in the south and the Danube River in the east to the foothills of the Carpathian Mountains and the South East Alps in the north and west (Fig. 1).

The period of interest, beginning with the Middle Eneolithic (Lasinja spindle-whorl sample representing the earliest tools) and ending with the Early Bronze Age (Somogyvarr-Vinkovci spindle-whorl sample representing the latest tools) falls roughly between the middle of the $5^{\text {th }}$ and the end of the $3^{\text {rd }}$ millennium BC. Within the geographically defined region, changing environmental conditions were investigated with the use of moderate-resolution climate simulations. In the investigation of change and possible innovation in fibre production and processing, both climate information and the recorded archaeological evidence were considered, analysed, compared and finally discussed for possible correlations.

\footnotetext{
3 Ljubljansko Barje-Ig and Dobanovci were excavated during the 1880s and the 1960s, while Gomolava and Slavča-Nova Gradiška are the only systematically excavated sites included in the study.

4 Kostolac: two sites (172 tools), Classical Baden: eleven sites (147 tools), Boleráz group: two sites (32 tools), Furchenstich complex: ten sites (205 tools), Lasinja: six sites (47 tools), Proto-Boleráz: one site (37 tools), Vučedol: two sites (38 tools), Somogyvár-Vinkovci: four sites (17 tools), Late Vučedol/Somogyvár-Vinkovci: one site (141 tool).
} 
The results of the comparative analysis present the impact of dynamic climatic conditions on two changes in textile production which influenced spinning technology: firstly, through the adaptation of the fibre material resources, and secondly, through the modification of final product demand. Both trends, occurring in the $4^{\text {th }}$ and becoming more pronounced in the $3^{\text {rd }}$ millennium $\mathrm{BC}$, were mainly quantitatively observed and discussed as the adjustment of tools' morphological, and thus functional features. Therefore, both their typological and functional variability were addressed.

The recorded trends in tool assemblages presented in this paper can be attributed to more than two suggested factors that may be equally culturally and environmentally promoted. Nonetheless, from the technological point of view, they are the most frequently discussed and considered in the framework of archaeological textile research as being the factors responsible for determining a tool's functionality (Loughran-Delahunt 1996; Grömer 2005; Mårtensson et al. 2006; Verhecken 2010). The approach presented here draws attention to prehistoric textiles in the archaeological record, which enables a closer insight into manufacturing traditions and production technologies that can benefit our understand- ing of social and cultural realities and their changed economic strategies.

Our main objectives were intended to:

(1) Explore and detect trends of change within the Pannonian Plain textile tool sample.

(2) Elucidate the chronological, cultural-historical and, to some extent, environmental context of these trends.

3 Model and interpret the main climate change trends within the geographical and chronological range of the research.

(4) Correlate both sets of trends and consider their connection.

5 Explore the idea of climate conditions within the spatio-temporal context of the textile production structures.

\section{Spindle-whorl analysis}

The metrical standards outlined above have to be considered cautiously, because the spinning process is influenced by a combination of many factors. In fact, recent extensive spinning experiments (Kania 2015) designed to shed more light on how fibre and yarn depend on the tool's weight and moment of inertia revealed how both of these variables have little to no influence when compared to the human

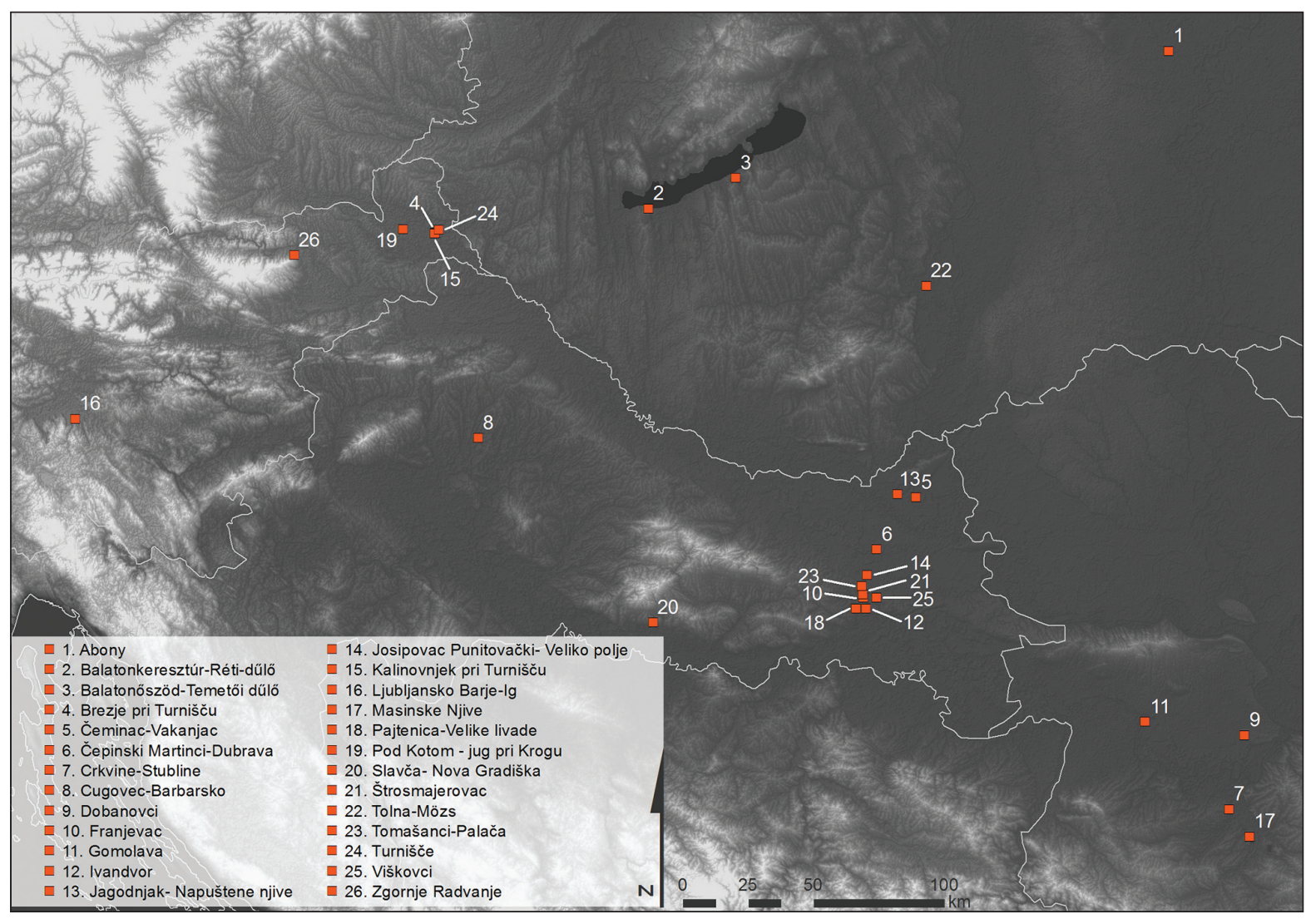

Fig. 1. The distribution of the sampled sites. 
factor. In other words, a skilled spinner can spin a variety of fibres with a variety of spindle-whorl types and produce a proportional variety of different yarns. In addition, Karina Grömer's experiments (Grömer 2005) showed that although very heavy suspended spindle-whorls $(120-140 \mathrm{~g})$ were not suitable for very fine yarns and light whorls (8-20g) were not efficient for thicker yarns, a medium weight $(40 \mathrm{~g})$ would be suitable for almost every thickness documented in prehistoric Europe.

Although the influence of the tool's weight and its moment of inertia can to a certain degree be overcome by the spinner's skill, the substantial difference in tensile strength between the two fibres investigated (fibre flax and early wool) should be distinguishable, if not in the distribution of medium spindle-whorl types, then in the distribution of extremely different tool categories. The functionality analysis was thus chosen as appropriate with regard to the big size of the considered sample and big difference in tensile strengths of the raw materials investigated. The sampling method accounts for the robust patterning; its purpose was to reveal interpretable trends in textile technologies within a broad chronological context. Although moderate spindlewhorl types are especially difficult to interpret, the significant difference between the distributions of extremely different tool types should be considered as an indication of substantial differences in spinning technologies.

During the three-year study, 1152 spindle-whorls were recorded in a textile tools database. Initially, the study included tools from 34 archaeological sites, but subsequently the final analysis was conducted on a limited sample of 836 spindle-whorls 5 . Each investigated cultural-historical group was documented at two or more sites, with the exception of the ProtoBoleráz group. Middle Eneolithic tools account for $34.6 \%$ (289), the Late Eneolithic for $42.0 \%$ (351) and Early Bronze Age for $23.4 \%$ (196) of the entire sample of spindle-whorls. The recording protocol was based on four main measurements (whorl diameter, perforation diameter, height and weight) and by calculating weight/diameter and height/diameter ratios. The ranges and mean values for all the recorded variables are given in the chart (Fig. 2).

The analysis segment of this paper reports on 328 whorls which were completely preserved, 163 whorls preserved in half, 223 partially preserved whorls and 122 whorls that had small fragments (less than $10 \%)$ missing 6 . All spindle-whorls in the database were documented in order to provide three separate categories of information: contextual, morphological and illustrative. Not all specimens provided equal amounts of information, and for the purpose of the functionality analysis a minimum criteria was applied: reliable chronological assignment, typological determination and the above-mentioned measurement standard.

In order to investigate the change in the metrical features of the spindle-whorls, the tools were divided into height-diameter and weight classes. This kind of typology served as a basis for their functionality analysis. The entire sample (836 spindlewhorls) was divided into three main weight types (light, medium, heavy) and height types (flat, high, and steep), according to the distribution of the spindle-whorl's height-diameter ratio and weight values (Fig. 3).

Additionally, due to the extremely high values, a fourth weight type was defined. The weight values

\begin{tabular}{|lccc|}
\hline Valid Number 836 & Min. & Max. & Mean \\
\hline diameter & 26.00 & 96.00 & 56.4011 \\
\hline height & 5.00 & 77.60 & 25.5841 \\
\hline perforation diameter & 3.50 & 17.00 & 7.9317 \\
\hline weight & 6.39 & 317.70 & 68.3354 \\
\hline height-diameter ratio & 0.10 & 1.32 & 0.4559 \\
\hline weight-diameter ratio & 0.14 & 4.25 & 1.1400 \\
\hline
\end{tabular}

Fig. 2. Table showing ranges and mean values for all the recorded variables in millimetres and grams.

\footnotetext{
5 The sample standard was set at a minimum of three recorded spindle-whorls with complete metric data and chronological placement. Furthermore, the Neolithic spindle-whorl sample was not included in the study. No Early Eneolithic spindle-whorls were recorded in the database, thus no continuity or change in textile production could be thoroughly investigated. Also, the climate simulations did not cover a substantial part of the period.

6 The weight values of the spindle-whorls in the sample were documented in four different reliability categories depending on their preservation status. The weights of complete samples were documented in the complete weights category; weights of almost complete samples with small fragments missing were documented in the estimated weights category (estimated weight $\approx$ weight if not complete); weights of samples preserved in half were documented in the calculated weight category (calculated weight $=$ weight if not complete doubled), and finally, weights of partially preserved samples were documented in the reconstructed weight category (reconstructed weight $=$ density x volume). Volume and density variables were provided from virtual (three-dimensional) models created for the partially preserved spindle-whorls.
} 


\begin{tabular}{|lccccl|}
\hline $\mathbf{N}$ & 836 & $\begin{array}{c}\text { height/diam. } \\
(\mathbf{m m})\end{array}$ & $\mathbf{( g )}$ & weight \\
\hline$(\%)$ & 10 & 0.20 & & 22.00 & \\
& 20 & 0.23 & FLAT & 27.40 & LIGHT \\
& 30 & 0.30 & & 33.00 & \\
& 40 & 0.35 & & 41.30 & \\
& 50 & 0.43 & HIGH & 56.00 & MEDIUM \\
60 & 0.52 & & 68.00 & \\
70 & 0.60 & & 82.00 & \\
& 80 & 0.68 & STEEP & 104.40 & HEAVY \\
& 90 & 0.80 & & 140.00 & (>VERY \\
& & & & HEAVY) \\
& & & & \\
& & & & &
\end{tabular}

Fig. 3. Table of height-diameter ratios and weight classes with considered values.

of very heavy spindle-whorls are generally connected to substantially long fibres and plying (Barber 1991.52; Hochberg 1979.21) heavier thick yarns or ropes (Vakirtzi 2014.53). Represented in 10\% of the entire sample, spindle-whorls weighing above $140 \mathrm{~g}$ were considered appropriate for the addition of the very heavy weight type, making this class associable with very long, presumably plant fibres and plying (Fig. 4).

As already mentioned, early wool was expected to have shorter fibre lengths, thus the $33 \mathrm{~g}$ upper limit for light spindle-whorl category was considered reasonable (making this weight type associable with wool) 7 .

\section{Model simulations}

To our knowledge, the results of climate simulations have not been employed so far to investigate changes in climatic conditions for a chosen region and determined period. The decision to adopt this particular approach as support for our analysis was made for several reasons. Firstly, the model allows full coverage of the area investigated for the entire period in question. Furthermore, the temporal resolution of such analysis allows us to focus on different temporal scales, leading to the representation of inter-annual to millennial climate variability. But, most importantly, besides allowing the simulation of possible changes of different climatic parameters, the model also allows us to find plausible physical interpretations for them. Nonetheless, as support for the conclusions based on the model results, we additionally address several studies which rely on proxy reconstructions.
A transient continuous climate simulation was performed with the coupled atmosphere-ocean circulation model ECHO-G, composed by the ECHAM 4 (Roeckner et al. 1996) and the ocean model HOPE (Wolf et al. 1997), at a spectral resolution of T30 (_ 3:750_3:750). The model was driven by changes in the Earth's orbital configuration calculated by Andre Berger and M. Loutre (2002), changes in solar activity as reconstructed by Sami K. Solanki et alii (2004) and variations in GHGs concentrations deduced from air trapped in ice cores (Flückiger et al. 2002). Further information on the simulation realisation is provided in Sebastian Wagner et alii (2007). The results of the aforementioned simulation have been used in different studies: within these Wagner et alii (2007) used the model results in order to investigate the Mid-Holocene hydrological climate in Southern Patagonia. Bijan Fallah et alii (2015), Jonas Berking et alii (2013) and Emannuele Russo et alii (2016) used the model's outputs in order to run a time-slices experiment for different areas and periods of study.

The region considered in our analysis extends from longitude $14 \mathrm{~W}$ to $21 \mathrm{~W}$ and from latitude $42 \mathrm{~N}$ to $48 \mathrm{~N}$, covering most of the Pannonian Plain region from the southern borders of Serbia in the south to Northern Hungary in the south. The analysis covered the period between $7000 \mathrm{BP}$ and $3000 \mathrm{BP}$, taking into consideration the different variables that were particularly relevant for plant growth, such as near surface temperature, humidity balance (i.e. precipitation minus evaporation) and rising temperature

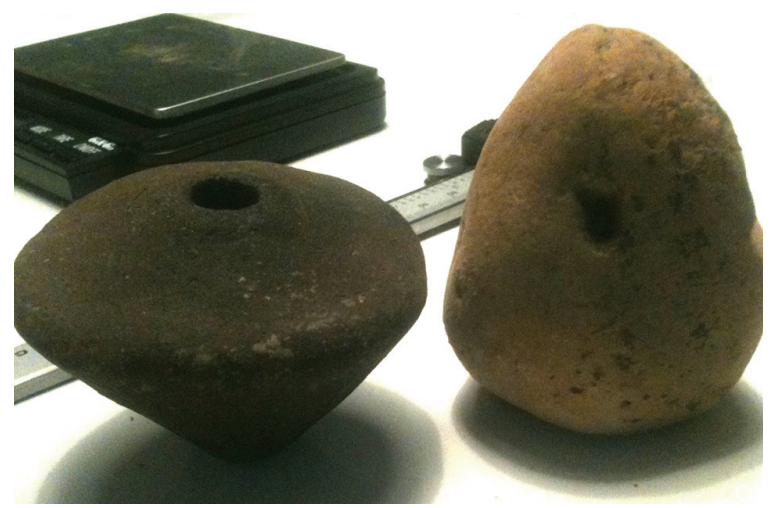

Fig. 4. Late Eneolithic spindle-whorl (from the Kostolac context) beside a Late Neolithic loom-weight from the Sopot context found at Slavča-Nova Gradiška, demonstrating the large size of the very heavy spindle-whorl type.

\footnotetext{
7 Compared to wool, plant fibres are more often considered to be spun with heavier weights Barber (Barber 1991.25). Very heavy whorls, respectively $100 \mathrm{~g}$ and above, could be connected with full-length flax or long-staple wool of later specialised breeds, while this amount of tension is supported only by very long fibres. For spinning medium to heavy wool more moderate weights would be more adequate, at around 30g, respectively (Gleba 2008.103-106).
} 
of days with above 5 degrees (Masson et al. 1999). Sea level pressure anomalies were also considered.

\section{Results}

\section{Adapting technologies}

Regarding the robust period to period comparison, the observed differences in spindle-whorls' weight and diameter distributions pointed to a significant increase through time in values for both variables. The lowest weight variability is obvious in the earliest (Middle Eneolithic) and the highest in the latest (Early Bronze Age) assemblage. Nevertheless, in the case of Early Bronze age tools, it is noticeable that the previously wide distribution of the Late Eneolithic values was limited to a noticeable degree in the frequency of the large diameter sizes (Fig. 5).

A similar trend can be observed regarding the correlated height-diameter and weight categories. In the earliest, Middle Eneolithic assemblage, light and medium weight types are convincingly predominant, and appear to be clustered in only one height group: the lowest category or the flat spindle-whorl type.
Almost the opposite distribution is evident in the latest, Early Bronze Age assemblage. Here, again, most of the tools cluster in one height group, but this time in the highest category of the steep spindle-whorl type. Although in this period all four weight groups appear to be more evenly distributed in this category, heavy and medium spindle-whorls are the most represented. The Late Eneolithic assemblage seems to fit the transitional period between these two extremes. First, because it shows the increase in the amount of heavy weight types, a trend which displayed continuity in regard to the Early Bronze Age period. Second, because the category of medium weight spindle-whorls revealed the most balanced distribution across all three different height groups, with the highest frequency occurring in the moderate (high type) height group (Fig. 6).

When analysed in the context of shape variability, the largest weights (heavy and very heavy spindlewhorl types) are mostly represented in the biconical and conical groups, those of the moderate size (medium weight spindle-whorl types) in biconical, conical, convex and discoid groups, while, finally, the
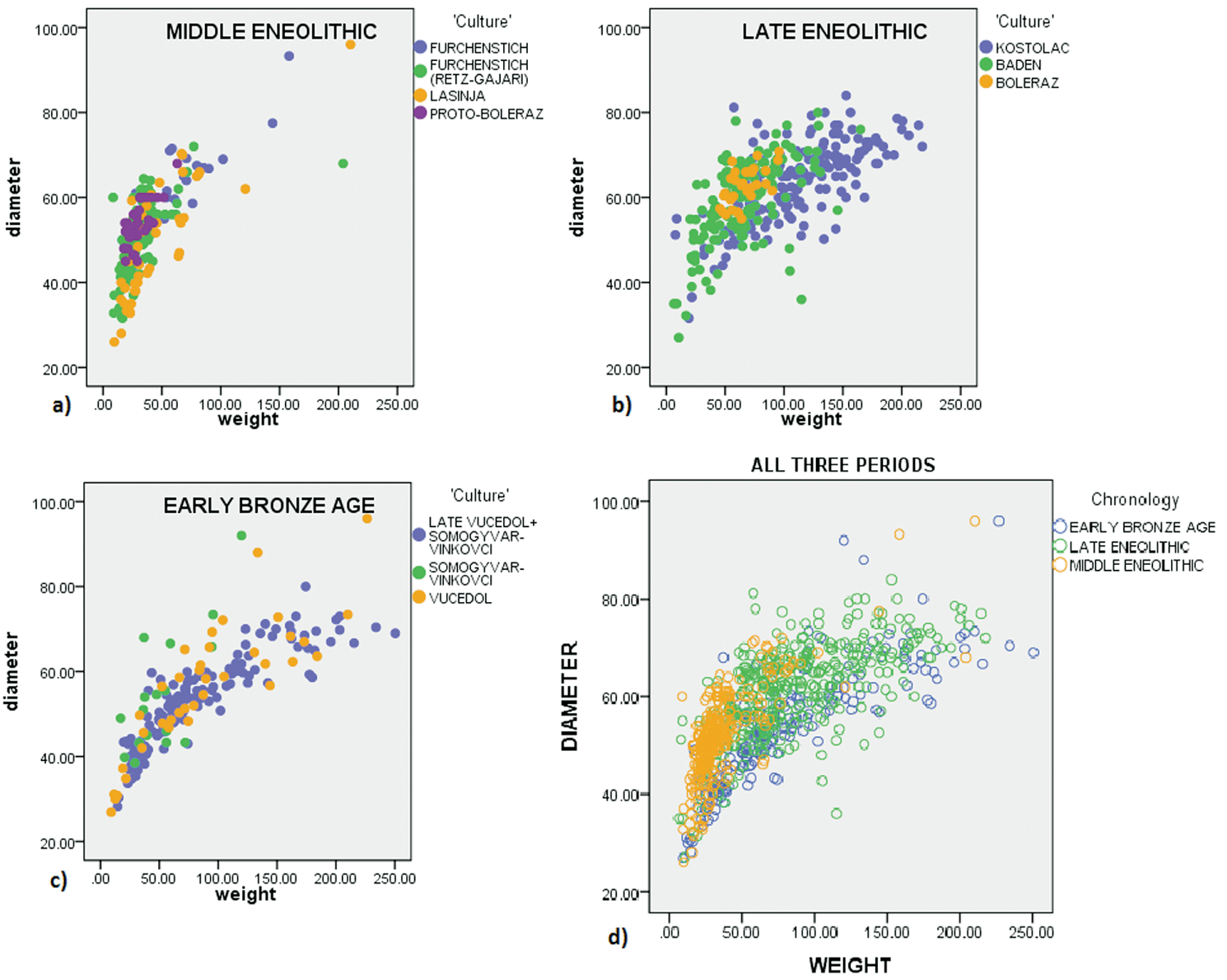

Fig. 5. The weight-diameter distribution for each period separately (a, b and c) and diameter-height distribution chart shown for all respective periods together (d). 

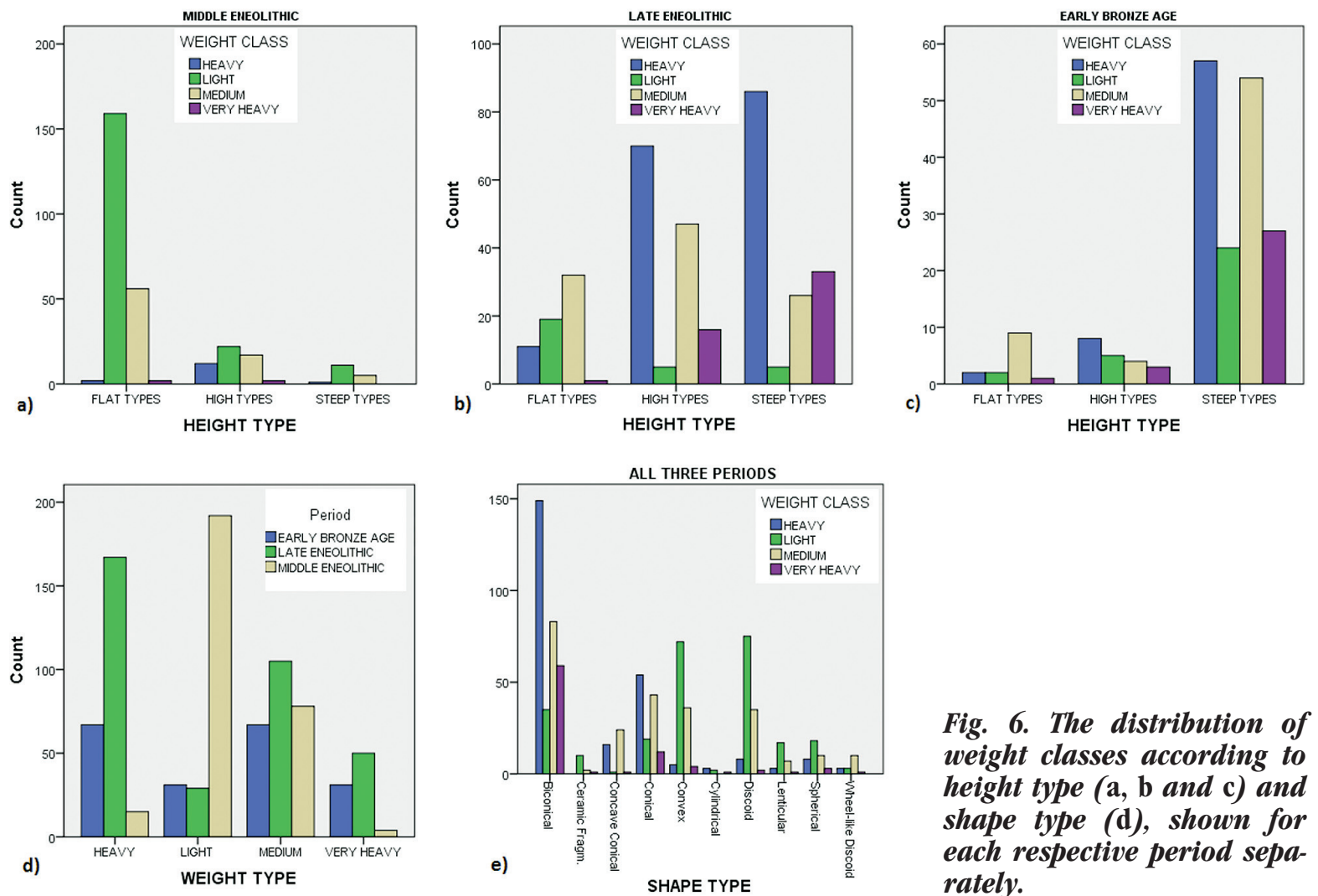

smallest weights (light weight spindle-whorl type) appear to be characteristic of the discoid, convex, and, again, biconical groups. Finally, it is obvious that biconical and conical spindle-whorl shapes account for the greatest weight variability in the sample (Fig. 6). Both types are most represented in the Late Eneolithic sample, while the biconical type is the single predominant type in the later, Early Bronze Age assemblage. Convex, followed by discoid types are convincingly the groups most typical of the earlier Middle Eneolithic assemblage (Fig. 7).

Although the maximum diameter and perforation diameter variables seem to behave quite proportionally to one another, it is possible to distinguish some preferences and tendencies when comparing periods. Smaller maximum diameters and smaller perforation diameters seem to be more typical of the Middle Eneolithic period, while the Late Eneolithic values cluster towards the higher spectrum in the case of both variables. Early Bronze Age values show

the greatest variability in their distribution, but even in this case, the inspected variables still correspond proportionally (Fig. 7). This parameter was primarily tested for samples with significantly non-proportioned correlations, since they would influence the ensuing assumptions, attributing a greater influence of spindles to the tools' rotation. These would substantially change generalisations regarding rotational properties, which are based solely on the whorls' morphological and weight parameters.

If we consider how the spindle-whorl's rotational characteristics, particularly its moment of inertia, depend on the tool's geometry and weight, a heavier whorl of significant height could have similar rotational properties to a much lighter tool of smaller height and bigger maximum diameter. The principals of this approximation, presented by Tomasz Chmielewski and Leszek Gardyński (2010), were used to compare widely defined height and weight categories of tools, not specific objects and values ${ }^{8}$.

8 Corresponding correlations were suggested by Chmielewski and Gardyński (2010.876): "the height-diameter ratio corresponds quite accurately with the modulation of the basic technical parameters of the tool that is its weight and angular mass. Changing both of the qualities influences the functional characteristics of a given spindle-whorl. For the increase in the angular mass of the tool, in order to slow down its rotational speed, it is purposeful to increase its maximum diameter (whereas this parameter will be characterised with the higher variability). On the other hand, if a high increase in the mass moment of inertia is undesirable (due to the use of shorter fibres that require more twist), but is needed to enlarge the mass of the spindle itself in order to create better yarn tension, the height of the spindle-whorl will increase rapidly, whereas diameter variability will be reduced." 

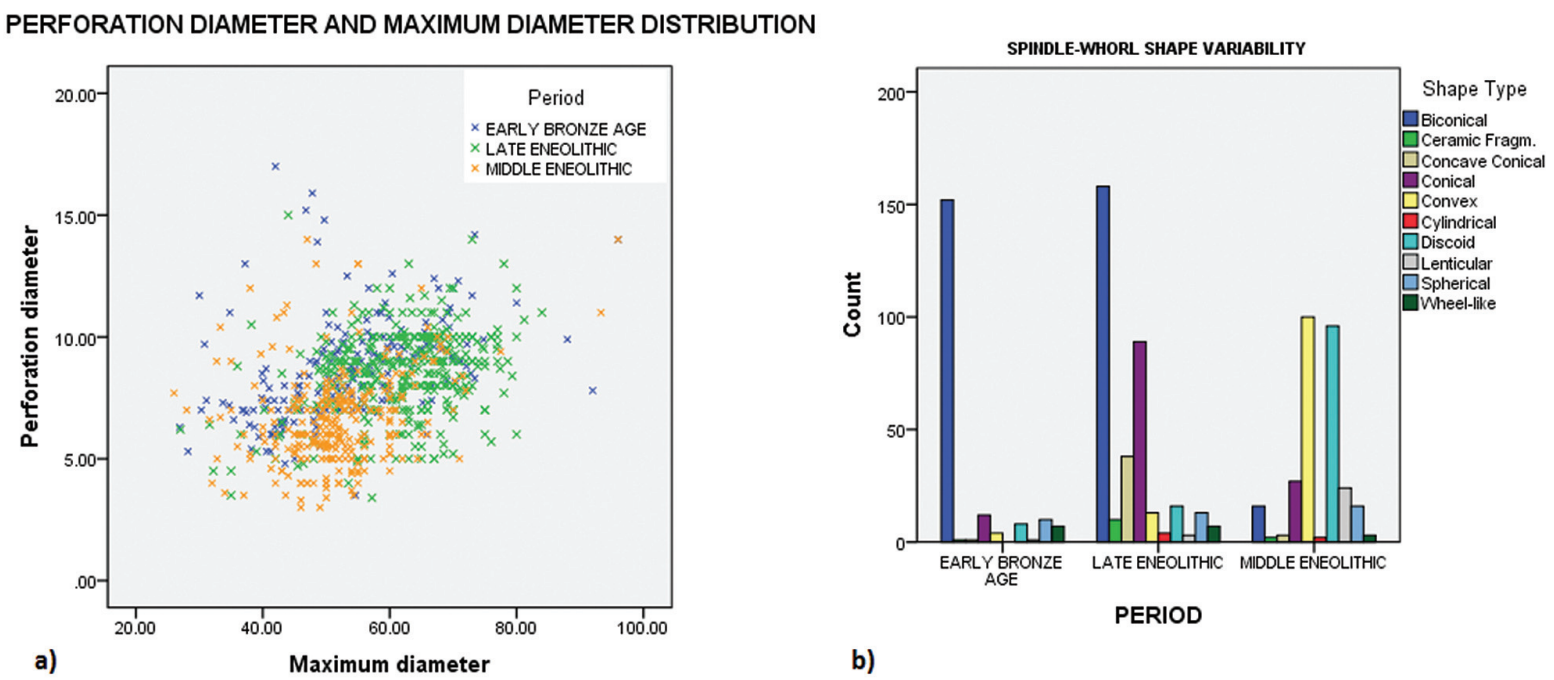

Fig. 7. The distribution of spindle-whorl maximum diameter and perforation diameter values (a). Histograms presenting their ratio variable distribution against period (b). The spindle-whorl shape type distribution for all three periods separately (c).

The differences in geometry among recorded spindle-whorl shapes enabled only rough comparisons and general assumptions. These were based on the expectation that a substantial increase in the spindle-whorl's height (Fig. 8) would lower the tool's moment of inertia if its weight remained constant.

Acceptance of this relational principle allowed further correlations between different weight and height types (medium-steep with light-high type, medium-flat with heavy-high type, heavy-steep with medium-flat type and light-flat with medium-steep type), based on their comparatively corresponding or rather similar rotational traits. If we consider these assumptions in the fibre material context it becomes obvious that the medium weight type from the middle-high height class is the most 'flexible' among all groups of spindle-whorls, presumably affording a comparable twist or tension performance with the greatest number of different category types (Fig. 9).

This accounts for the Late Eneolithic transitional character in the technological sense, since it shows how the most 'flexible' spindle-whorl category is highly represented in its assemblage when compared to samples from the other two periods (Fig. 6). The greatest height type variability in the Late Eneolithic assemblage could be interpreted as the intentional manipulation of the tool's height properties, possi- bly due to the avoidance of a drastic increase in the spindle-whorl's mass moment of inertia. This kind of tool adaptation is desirable, for example, in processing shorter and lighter fibres which require more twist, while the enlargement of the mass of the spindle itself is intended, for instance, to obtain better yarn tension (Chmielewski, Gardyński 2010.870).

During both the Middle and Late Eneolithic period, light steep types of spindle-whorls are under-represented, but in the case of the light high types, the Middle Eneolithic shows an increase in frequency, which could be associated with wool spinning. Additionally, the recently reported results of a technological analysis of $4^{\text {th }}$ and early $3^{\text {rd }}$ millennium BC textile tools from Arslantepe in Turkey (Laurito et al. 2014) support this conclusion. Furthermore, the above-mentioned spinning experiments were designed to prove that the wider hemispherical and heavier spindle-whorls (comparable to the light high type) were the most efficient tools in terms of quantity and quality of yarn. Also, this category proved to be proficient in processing both vegetal and woollen fibre and suitable for all thread thicknesses9. Interestingly, the single bone spindle-whorl in our sample 10 closely resembles (in shape, method of production, and recorded size and weight values) the aforementioned $4^{\text {th }}$ millennium bone tools from Arslantepe, proposed for spinning wool (Fig. 10). It

\footnotetext{
9 Surprisingly, it has been suggested that the smaller and lighter clay spindle-whorls from Arslantepe were unsatisfactory for spinning wool. Furthermore, authors explain how their moment of inertia was too small for short animal fibres, pointing out that wool used in the experiment had presumably longer fibre lengths than early wool. They do propose that metal spindles might have been used to increase the moment of inertia of the small whorls, making them suitable for spinning animal fibres (Laurito et al. 2014). 10 Bone spindle-whorls are very rare in the Pannonian Plain during this period, and the particular find was initially published as a bone pendant (Čataj 2009.31).
} 


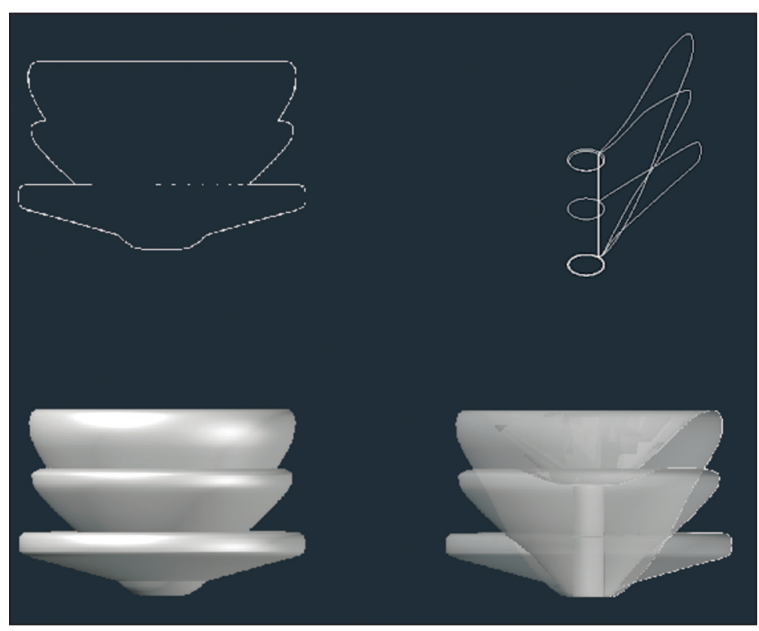

Fig. 8. Reconstructed three-dimensional models of a flat, high and steep spindle-whorl type, based on published conical spindle-whorls found at the Balatonoszod-reti dulo site (Horváth 2013).

should be mentioned how the results of another recent analysis (Vakirtzi 2014) of North Aegean Early Bronze Age tools from Thasos also suggest that this particular spindle-whorl weight class was used for spinning wool.

Both light high and light steep tool categories become significantly more represented in the course of the $3^{\text {rd }}$ millennium, as shown by the Early Bronze Age assemblage. These types, including the medium steep type (if we accept the approximated comparisons explained), which is more substantially represented in the Late Eneolithic sample, and the second most frequent type in the Early Bronze Age sample, could be appropriate for spinning shorter fibres, presumably wool (Fig. 6). These medium steep types, although heavier, are expected to have a significantly lower moment of inertia due to their geometry, or more precisely, their higher height-diameter ratio.

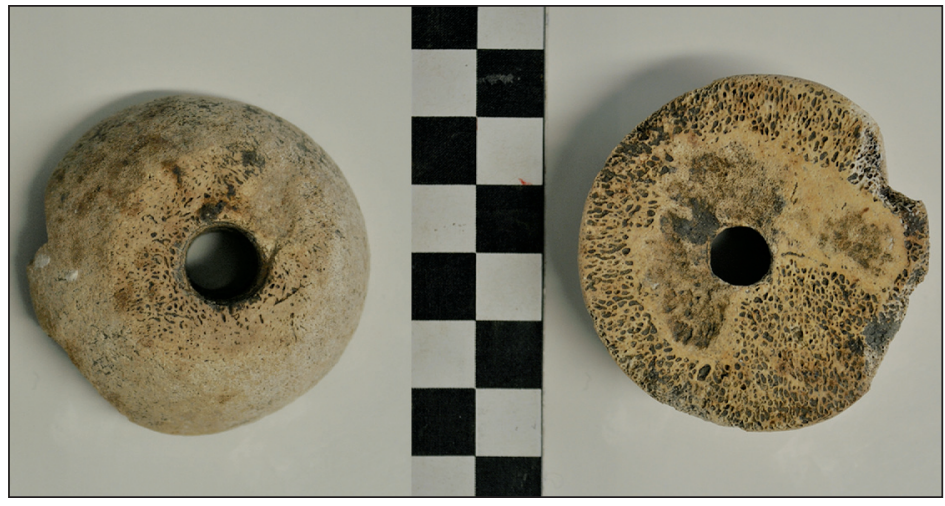

Fig. 10. A convex spindle-whorl made from the head of a cattle femur bone, weighing 24.6g, from a Furchenstich (Retz-Gajary) context found at Josipovac Punitovački-Veliko polje, dated to the $1^{\text {st }}$ half of the $4^{\text {th }}$ millennium BC (Middle Eneolithic period).

\section{HEIGHT/DIAM. \\ WEIGHT}

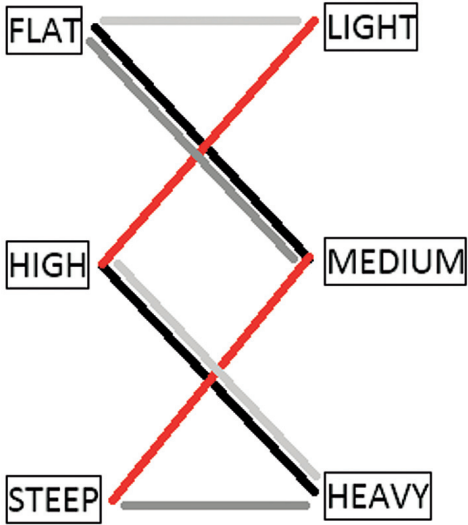

Fig. 9. Diagram of corresponding height and weight types.

On the other hand, heavy and very heavy types could be connected to processing long plant fibres. Although they have larger height-diameter ratio values and tend to cluster in the high and steep height groups, their weight leads to significantly larger moment of inertia values (too big for processing short or even moderately long fibres that call for more twist). Additionally, their weights alone are too big for the lower tensile strengths of animal fibres. Thus they can be considered appropriate for spinning long plant fibres such as full-length flax. These spindlewhorl types become predominant in the late $4^{\text {th }}$ millennium and continue to be highly represented in the ensuing $3^{\text {rd }}$ millennium assemblage, as shown by the distribution charts for the Late Eneolithic and Early Bronze Age samples (Fig. 6).

The technological development did not reveal a linear process leading 'from plant to animal' fibre production. As shown by the trends in maximum heightmaximum diameter and maximum height-weight correlations, the dynamics of the use of fibre material was more complex (Fig. 11). The greatest height value variability apparent in the Late Eneolithic period is lowered in the $3^{\text {rd }}$ millennium BC sample. Frequency of the lowest height values is decreased, while the maximum diameter distribution clusters towards the lower values.

\section{Climate conditioning}

The climate of the Holocene was highly variable, and multiple controls must have been responsible for this variability (Mayewski et al. 2004). According to Heinz Wanner et alii (2009), the Holo- 

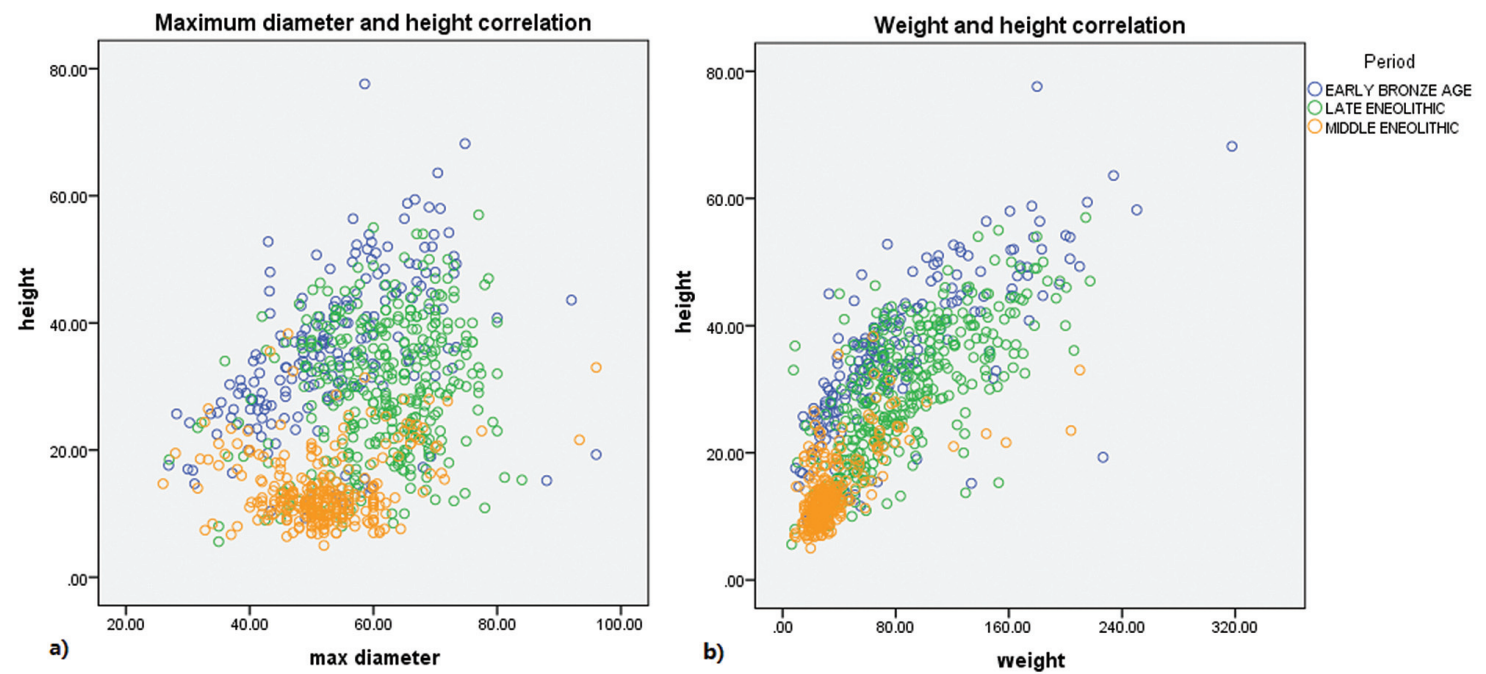

Fig. 11. The distribution of correlated: a maximum diameter and height values; $b$ weight and height values, for the three period assemblages together.

cene climate was dominated by the influence of summer season orbital forcing; our results are in accordance with this interpretation. In particular, our model simulations revealed that from the $7^{\text {th }}$ millennium BP, summer climatic conditions started to deteriorate in the middle latitudes of the Northern Hemisphere (NH), mainly due to a decrease in summer insolation, which reached its maximum at around $9000 \mathrm{BP}$ (not shown). For all the simulated climatic parameters, a pronounced trend is evident for the summer season, which resembles one of a complete decrease in insolation (Fig. 12), although the humidity balance reveals an opposite, increasing trend, mainly due to the effect of evapotranspiration as a consequence of the enhanced insolation in the mid-Holocene.

Such conclusions are also supported by other studies based on proxy reconstructions for the investigated area and its surroundings. In particular, by analysing Holocene conditions through pollen reconstructions from several lakes, in Southern to Northern Italy and the Alpine region, Michel Magny (Magny et al. 2012) concluded that the mid-Holocene summer precipitation regimes appear to have been opposite between the south- and north-central Mediterranean: a maximum was present in Sicily and a minimum in north-central Italy. Later, Magny et alii (2013) analysed a time series of wetness for the Lake Ledro basin in Northern Italy spanning the last 10000 years: while the early and mid-Holocene periods show relatively low flood frequency, the late Holocene, from $c .4500$ cal BP onwards is characterised by an increase, which is in full agreement with the reconstructions from neighbouring Lake Iseo. The pattern of contrasting mid-Holocene summer precipitation regimes was confirmed by Odile Peyron et al. (2013) on the basis of pollen-inferred quantitative estimates and a multi-method approach that revealed minima (maxima) of summer precipitation and lake levels to the north (south) of $c .40^{\circ} \mathrm{N}$. Summer temperature showed a similar partition for the mid-Holocene in the central Mediterranean, with warmer (cooler) conditions to the north (south). Mónika Tóth et alii (2015) presented a Holocene summer air temperature reconstruction based on fossil chironomids from Lake Brazi, a shallow mountain lake in the Southern Carpathians, with results suggesting that from $c .8500 \mathrm{cal} \mathrm{BP}$, chironomid-based summer temperatures decreased in the area. In particular, the period between 6000 and $3000 \mathrm{cal} \mathrm{BP}$ was characterised by cooler temperatures in comparison to the earlier period.

Conversely, winter-time model results do not show a clear trend and the data are characterised by significant multi-decadal to inter-centennial fluctuations (Fig. 13). For winter, the trend of insolation during the mid-to-late Holocene at the mid-latitudes of the $\mathrm{NH}$ is not particularly pronounced (Fig. 13). The behaviour of the simulated data is probably a result of the system's internal variability. In winter, climatic conditions in Europe are mainly driven by changes in atmospheric circulation (Hurrel 1995; Hurrel et al. 2003). In particular, the first mode of winter atmospheric variability over the North Atlantic is represented by the North Atlantic Oscillation (NAO), which explains one third of the total variance in the sea-level pressure (SLP) field over the area (Hurrel et al. 2003). A positive phase of the winter NAO is associated with an increase in strength and a northward shift in westerly winds. This results in moist 

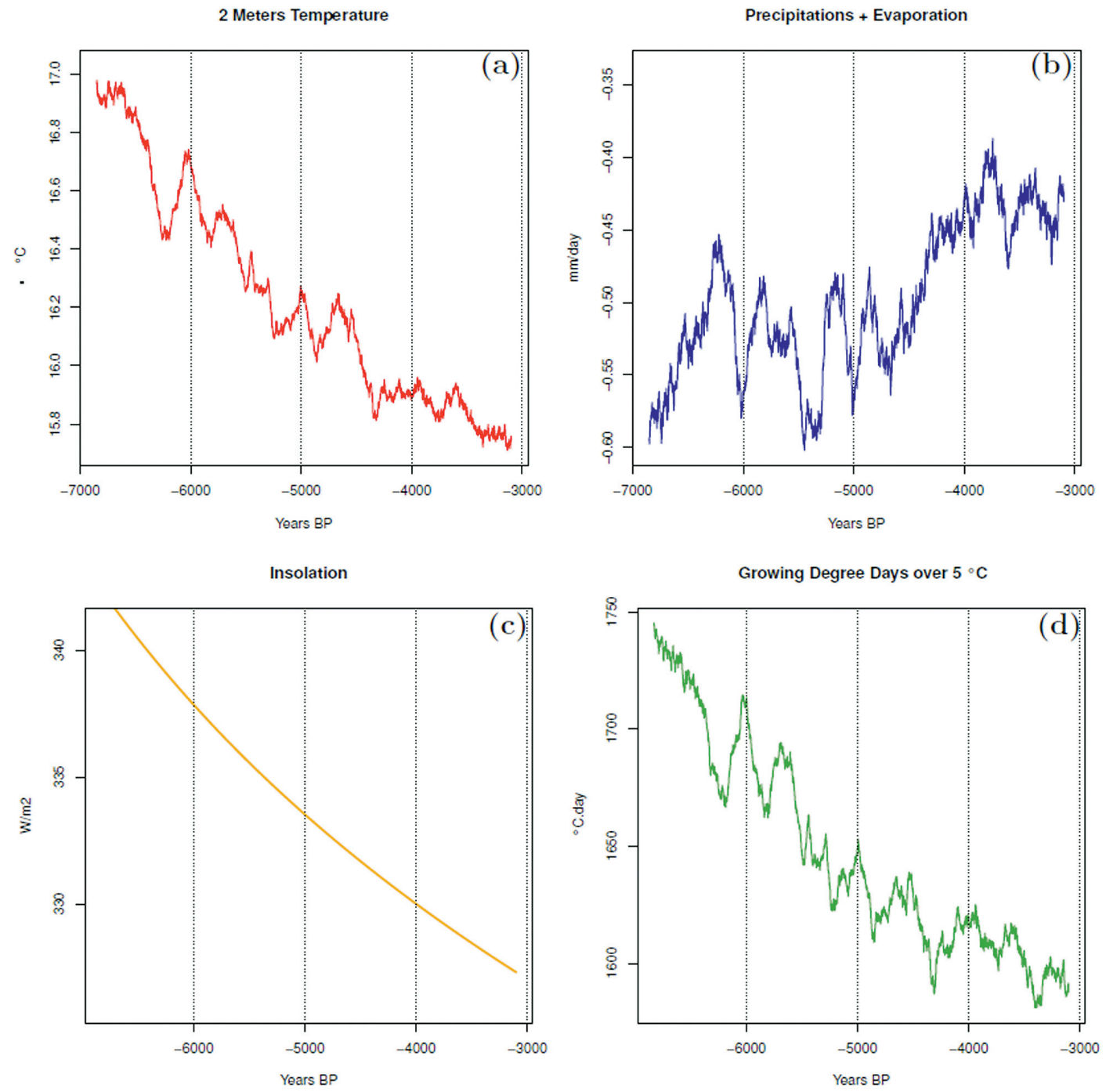

Fig. 12. Graphs presenting: a summer temporal evolution of near-surface temperature regional mean computed over the area of study; b time series of summer precipitation + evapotranspiration calculated in mm/day; c insolation changes over the period of study; dime series of rising temperature days above 5 degrees. All the time series are smoothed using a 200-year running mean.

and warm air advection from the Atlantic to Northern Europe $\left(55^{\circ}-70^{\circ} \mathrm{N}\right)$ and, consequently, in drier and colder conditions over Southern Europe. Conversely, the negative phase of the NAO is accompanied by weaker and southward shifted $\left(35^{\circ}-50^{\circ} \mathrm{N}\right)$ westerlies, responsible for wetter and warmer winter conditions over Southern Europe. The use of the NAO index (Fig. 12.a), which is based on the principal component time series of the leading Empirical Orthogonal Function (EOF) of the winter SLP anomalies (Hurrel et al. 2003), allows us to speculate that the oscillations of the simulated winter temperature and precipitation are caused by the variability between positive and negative phases of this atmospheric pattern. The simulated winter temperature, and particularly humidity, present an extremely high anti-correlation $(\sim-0.7)$ with the calculated NAO index.
Different studies hypothesise that at around $6000 \mathrm{BP}$ the NAO was in a more pronounced positive phase in comparison to present-day conditions (Bonfils et al. 2004; Braconnot et al. 2007a; 2007b; Davis et al. 2003; Mauri et al. 2014; Russo et al. 2016). This is not directly evident in our results and seems to be a problem characteristic of climate models. Nevertheless, the changes in the simulated winter conditions can be considered physically consistent: the model simulates a reasonable and internally consistent climate (Goosse 2012; Von Storch 2004). Other events often reported in studies that are based on proxy-reconstructions are the so-called Rapid Climate Changes (RCC) (Mayewski et al. 2004; Budja 2015; Weninger et al. 2009; 2015; Wanner et al. 2011). They are abrupt cooling events, lasting from a century to millennia, for which large drifting ice debris has been registered. The complexity of our model 

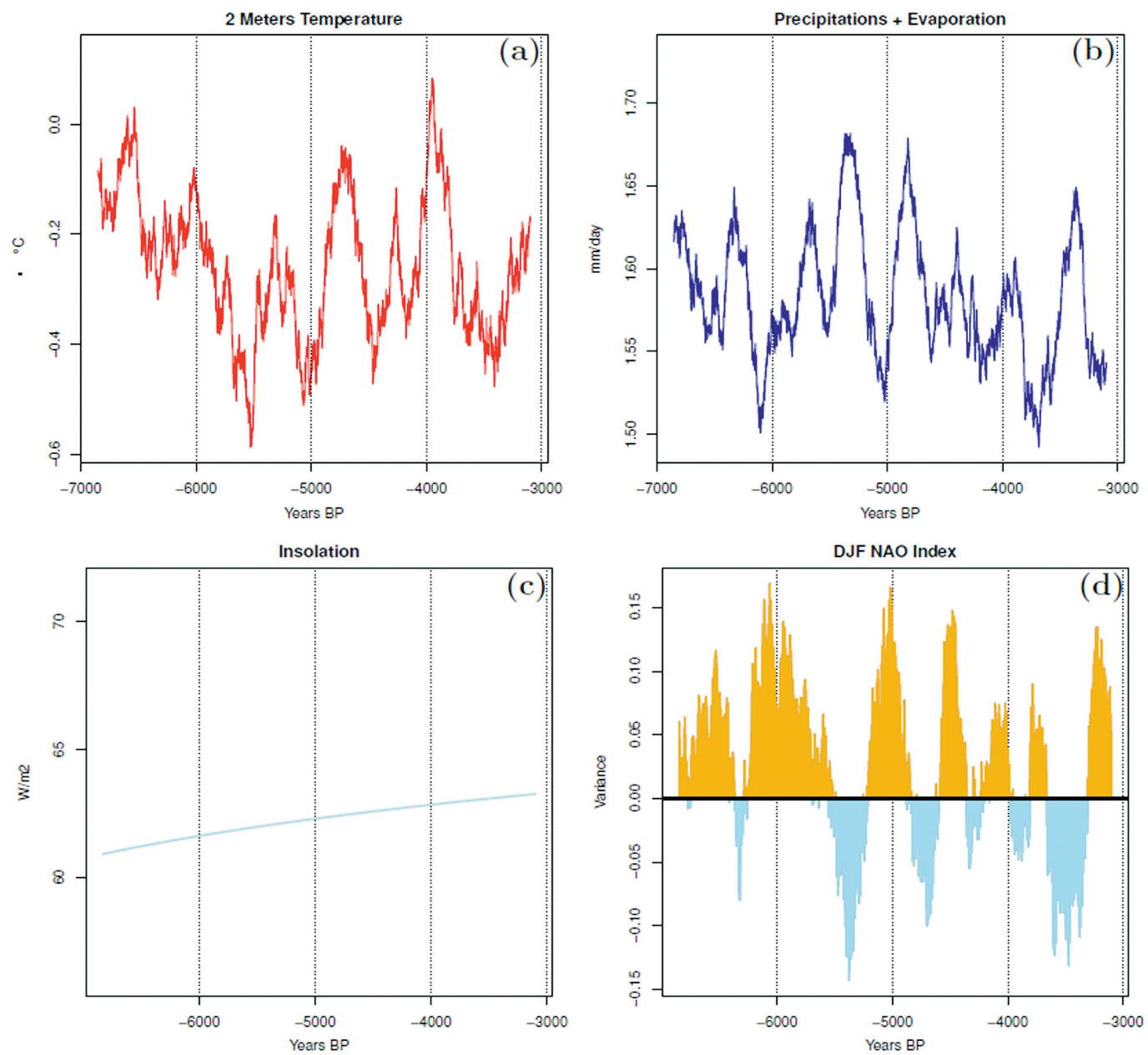

Fig. 13. Graphs presenting: a winter temporal evolution of near-surface temperature regional mean computed over the area of study; b time series of winter precipitation + evapotranspiration calculated in mm/day; c insolation changes over the period of study; d DJF NAO index over the period of study. All the time series are smoothed using a 200-year running mean.

does not permit a precise reproduction of such events. Additionally, even if evidence supporting them seems clear, their cyclic occurrence and causes are still highly debated, as well as the impact they had on a regional scale (Wanner et al. 2011). This is one of the main reasons we focus our attention on long-term trends and the relevance of abrupt oscillations in the context of population adaptability.

Nonetheless, in our discussion, we take into consideration one particular example of RCC and the possible impact it had on the life of Eneolithic communities inhabiting the area. Although in the case of winter, no distinct trend is evident in our simulations, and the model results do not display the same level of correspondence with the other studies (as they do in the case of summer, particularly temperatures and moisture balance), the evident oscillations are physically plausible. Thus, acknowledging the possibility of the effects of RCCs during the simulated period does not contradict the model results at all. On the contrary, it means that if those events occurred, they only contributed to the evinced deterioration in climatic conditions.

\section{Discussion}

The period between the mid-5th and the end of the $3^{\text {rd }}$ millennium $\mathrm{BC}$, in which the spread of both fleece-bearing sheep husbandry and new fibre flax in South East and Central Europe probably occurred, was characterised by profound social changes and has been studied so far in terms of intensified contacts and mobility (Anthony 2007; Leary 2014), environmental change (Binford 1968; Barker 1985) and economic transformation (Sherratt 1981; 1997; 2006; Greenfield 1988; 2005). This provided the entire contextual framework and theoretical background for the present investigation of textile production trends and their climate dependency in the aforementioned regions. Apart from the extensive research on textile production in Romania (Mazare 
2014) and Bulgaria (Petrova 2011), which took into consideration indirect archaeological evidence from larger and confined geographical sections, the textile tools and production of the period have not yet been systematically approached in the Pannonian Plain contexts. Narrowing the focus on the particular region enabled us to raise specific questions regarding textile fibre raw materials and final product demand through their dependence on the changing climate. The declining summer trend in temperatures and the corresponding rising trend in moisture content might have caused the cultural-historically defined groups of the Post-Neolithic inhabiting the area to be more sensitive to possible climatic fluctuations like the simulated winter oscillations. Such events could have acted as a trigger for shifts in fibre procurement practices, resulting in a broadening of resources and, especially, in intensified selection in favour of their fitness.

Evidence has shown that the period between 6000 and $5000 \mathrm{BP}$, normally referred as a Rapid Climate Change event, was generally characterised by globally colder conditions (Weninger et al. 2009; 2011; Mayewski et al. 2004). In this case, the effects of the proposed scenario of a deterioration in climatic conditions would eventually have been amplified, and abrupt changes could have had even more drastic effects on the 'cultural groups' under consideration. Through a complex causal network, this could have led to substantial perturbations within human societies, as suggested by changes in the archaeological material in Central Europe (Arbogast et al. 1996; Berglund 2003; Magny 2004). Weninger et alii (2009) found that at different times in the $6-5 \mathrm{ka}$ RCC period, there were abrupt abandonments of various settlements in Romania, Bulgaria, and Greece. During the same period in the Alpine region, abrupt oscillations on the scale of decades or a century seem to have caused changes in hunting and farming patterns (Schibler 1997).

The high-quality organic preservation at Sipplingen, an Alpine lakeshore settlement on the northern shore of Lake Constance in south-west Germany, en- abled comprehensive dendroarchaeological, archaeobotanical and zooarchaeological investigations that revealed the adaptive character of the settlement and its subsistence strategies in response to changes in climate, environment and cultural influences over time (4000-2800 BC) (Styring et al. 2016.103). Obvious economic changes that occurred during the $4^{\text {th }}$ millennium $\mathrm{BC}$, which have been attributed to climatic deterioration (Schibler et al. 1997), reveal a dramatic cycle of establishment, expansion and reduction, or even abandonment of settlements around Lake Constance (Billamboz, Köninger 2008). A great deal of evidence of flax cultivation has been found from lake dwellings north of the Alps, (Jacomet 2009). In particular, the find densities of flax rise considerably during the second half of the $4^{\text {th }}$ millennium BC (Brombacher, Jacomet 1997.249).

It is most likely that during the Middle Eneolithic period, which marked the turn and the first centuries of the $4^{\text {th }}$ millennium $\mathrm{BC}$, animal products, presumably including fibres, started to be more important as a result of deteriorating climate conditions. All the scarce textile evidence favours wild plant species, but the functional analysis of the Furchenstich and Lasinja spindle-whorls suggests that during this, apparently, intensive foraging period, animal fibres should not be disregarded. Faced with an environmental challenge due to the whimsical climate in the following centuries of the $4^{\text {th }}$ millennium $\mathrm{BC}$, in the context of intensified textile production, foraged plant material and possibly the old variety of flax might have been partially substituted with a new fibre fax in order to meet the growing demands of textile production. It is premature to conclude this, but the above-mentioned archaeobotanical research supports this idea.

The earliest direct evidence of wool, respectively woollen finds from Germany (Rast-Eicher 2014.16) and the North Caucasus (Shishlina et al. 2003), when observed in the framework of changed herding strategies revealed in the contemporary contexts of South East and Central Europe ${ }^{11}$, intensified sheep husbandry recorded at some sites 12 and the spin-

11 Regarding Central Europe, analysed faunal evidence from the Bronocice site in South Eastern Poland (Pipes et al. 2014) suggest that sheep rearing intensified during the second half of the $4^{\text {th }}$ millennium BC (Funnel Beaker horizon). Indeed, the increased herd sizes reported from the site revealed that the majority of animals were slaughtered as adults. In the case of South Eastern Europe, analysis of Late Eneolithic faunal samples from the Bubanj and Mokranjske Stene-potkapina sites in Serbia suggests the predominance of sheep husbandry (Bulatović 2012; Bulatović, Milošević 2015). Furthermore, analysis of the age profiles from the Mokranjske Stene-potkapina sample attributed to the Kostolac-Cotofeni horizon (late $4^{\text {th }}$ to early $3^{\text {rd }}$ millennium BC) revealed that the adult age group was the most represented.

12 Intensified sheep husbandry was recorded at the Middle Eneolithic Furchenstich site at Pod Kotom - jug pri Krogu I/II (Šavel 2009), at the Middle to Late Eneolithic Proto-Boleráz site at Abony (Fábián 2008; 2012), and at Late Eneolithic Boleráz/Baden sites at Balatonôszöd-Temetôi dúloó (Horváth 2010) and Balatonkeresztúr-Réti-dúlő (Fábián 2014). 
dle-whorl analysis results, push the presence of wool in the context of fibre production already into the $4^{\text {th }}$ millennium BC.

Following the results of our analysis and according to the aforementioned studies, it is very likely that the middle of the $4^{\text {th }}$ millennium BC (characterised by the appearance and spread of Baden culture in the Pannonian Plain) was a period of major climatic stress. Such pressure probably promoted further mastering of both fibre resources, thus influencing their specialisation. Intensified sheepherding is usually connected to this cultural group (Maran 1998.514-516), and many authors propose its acquaintance with wool (Horvath 2010; Bondar 2012; Struhar et al. 2014). On the other hand, the level of flax pollen in samples from lake-shore settlements in Switzerland indicates intensive flax production, more recognisable in the frequent textile remains (Capitani et al. 2002. 115-120). This allows us to speculate that, during the course of the second half of the $4^{\text {th }}$ millennium $\mathrm{BC}$, both fibre materials gained in importance.

By the beginning of the $3^{\text {rd }}$ millennium $\mathrm{BC}$, such strategies had already been mastered and spread, since textile production does not seem to have slowed down at this point. On the contrary, judging by the increase in the amount of spindle-whorls from the end of the Eneolithic period, it seems it even intensified. More organised fibre material resources had to have been acquired and established by that period. Both the changed environmental and cultural conditions resonated further in the new demands for specific types of textile products, which quite possibly corresponded to the intensified use of transport and traction. The predominance of very large tools, probably used for plying plant fibres or their filaments in order to make thick and strong threads and ropes which could have been used for harnessing animals, would support this scenario. Mobility and the transport of goods would also have promoted the trend. The increased variability of Late Eneolithic spindle-whorl assemblages in favour of a balanced distribution of moderate weight types between three main height categories is something that might reflect this kind of broadened fibre assortment, both in regard to the raw material resources and demand for end products, although the obvious predominance of heavy and very heavy types of tool, particularly in high and steep height categories, greatly accounts for longer plant fibre preferences. This trend is particularly pronounced at the turn of the millennium, and continues in the Vučedol and Somogyvar-Vinkovci phase. There is a pos- sibility that this reflects the appearance of specialised fibre flax and its intensified use in the plying tradition of the late $4^{\text {th }}$ and the following $3^{\text {rd }}$ millennium BC. Impressed plied cord decoration (Grömer, Kern 2010; Leghissa 2015) representative of the Early Bronze Age Corded Wear complex (widespread in the Pannonian Plain) could attest to the growing importance of plied cordage in the course of the following centuries.

\section{Conclusions}

Three main trends are evident in the spindle-whorl sample. First, the Middle Eneolithic assemblages suggest more intensive animal husbandry, which led to the first exploitation of animal fibres. Second, on the basis of the Late Eneolithic tools, continued use of wool may be argued, which was substantially accompanied by the intensified production of long plant fibre, presumably flax. And third, the results of the analysis of Early Bronze Age spindle-whorls reveal a specialisation of fibres, most probably due to the refinement of both textile fibre resources and demand for final products.

Despite the large textile tool sample on which this research is based and regardless of the climate conditions that support the outlined timeline for the introduction of both sheep wool and the new fibre flax, already during the Eneolithic in the Pannonian Plain, further zooarchaeological and archaeobotanical evidence is required to understand and explain the dynamics of these processes in finer detail. The exploration of the new fibre resources occurred simultaneously in remote contexts and could have been provoked by both cultural and environmental conditions.

Numerous interacting factors were probably responsible for the intensification of their exploitation and, to some degree, their further development, which might not have been as linear as we thought. Thus their evolutional character is contrary to the revolutionary scenario. They gradually developed from ordinary foraged fibres into occasional and then into common secondary products. Due to the intensification of their use, they finally became primary and specialised resources for developed textile production. It is plausible that, due to different factors in different areas and periods, similar reasons promoted fibre production as those that later contributed to their specialisations. Although the earliest direct evidence for wool in the studied region dates to the $2^{\text {nd }}$ millennium BC (Grömer et al. 2013; 
Rast-Eicher, Bender Jørgensen 2013), its much earlier presence must be considered.

There are two possible reasons why in Europe the scant textile evidence sample from the $4^{\text {th }}$ and $3^{\text {rd }}$ millennium lacks woollen examples: first, its underrepresented use in comparison to flax and other plant fibres, and second, the fact that the European climate is not conducive to its preservation conditioning (Ryder 1964). Regarding resources for fibre production, the Middle Eneolithic could mark their initial exploitation phase, while the Late Eneolithic, with evident technological change which gradually resulted in greater tool standardisation in the Early Bronze Age, marks their second exploitation phase. The exploration phase for both resources might have already started in previous periods, and so future textile research of Early Eneolithic tools might clarify this dynamic. The results of the analysis suggest that in the studied region of South East and Central Europe, wool was probably already being exploited in the $4^{\text {th }}$ and certainly the $3^{\text {rd }}$ millennium $\mathrm{BC}$, although on a smaller scale, first in comparison to flax, and also in comparison to the established wool economies of contemporary urban centres in the Near East.

The continuous deterioration in summer climatic conditions in the Pannonian Plain region during these two millennia would still have provided conditions congenial to fibre flax. Areas with less favourable conditions for cultivating it might have focused their developing textile production on other resources, causing them to specialise in alternatives. This is a question of difference in fibre specialisations, which so far have been interpreted as indications of use, creating an unacceptable dichotomy in the period of intensified mobility and contacts. A growing demand for raw materials, and metal in particular, resulted in intensified trade that could support this kind of fibre competition through division in specialisation during the $4^{\text {th }}$ millennium, while textiles, and presumably fibres, may have been substantially involved in both short- and long-distance trade. Metal objects were certainly accountable for far-reaching cultural contacts, possibly facilitating breed mobility, which then accelerated the gene flow and the evolution of both fibres. Copper axes from burial mounds at Moravian TRB-Boleráz sites were wrapped in flax textiles, which could account for a combination of two luxury goods (Baldia et al. 2008.264-265). Sherratt (Sherratt 1997; 2006) connected both the animal traction and wool with social stratification, explaining them as symbols of elites. Quite possibly, this connection should be to some extent related to inequalities between animals and plants reflected in the people who had privilege to select among them. Although wool's appearance and origin were for a long time considered within the textile economies of the urban revolution package in Bronze Age Mesopotamia (McCorriston 1997; Kimbrough 2006), the oldest finds, genetic evidence, and the analysis of the prehistoric textile tools pushed its early appearance on the fibre scene into a new and much wider framework regarding its theoretical (SPR), geographical (Fertile Crescent), chronological (Bronze Age) and social (stratified organised systems) context.

On the other hand, archaeobotanical research on the flax plant, taken in consideration with the processed textile evidence from circum-Alpine pile dwellings, place the fibre evolution in the same period of the thriving copper trade in the $4^{\text {th }}$ millennium $\mathrm{BC}$, suggesting that both resources were exploited in the production of Eneolithic textiles. Although both scenarios were connected to many cultural and environmental trends, climate change was certainly accountable, if not for their evolution, then for influencing the dynamics of their exploitation.

During the late $4^{\text {th }}$ and early $3^{\text {rd }}$ millennium BC, an interesting example of a technological shift occurred, one which accommodated to both new options of presumed raw material resources, and new demands for a seemingly greater variety of end products. The moderate weight types of spindle-whorls significantly represented in all height classes during this technological phase suggest that all of the fibres considered could have been used. This was evidently accomplished through a gradual change in tool properties, while assemblages were consecutively adjusted.

Although the boom in heavy and very heavy types of spindle-whorls is more obvious and easier to connect with long plant fibres, and the appearance of smaller sizes in the Early Bronze Age is something we search for when we expect wool use, the modest, ordinary, average, hard-to- interpret type of tool revealed the biggest evolution: craftsmens' slow and gradual accommodation to the world around them. Technology's potential to be modified is mainly reflected in the outlined tools' flexibility. Although its moderate and gradual transformation does not account for a high degree of specialisation, it does reveal our ability to combine tradition and innovation in altering and, more importantly, challenging circumstances. 
We would like to thank the TOPOI Excellence Cluster for making this research and cooperation possible, especially our A4 - TEXTILE REVOLUTION and A2 - THE POLITICAL ECOLOGY OF NON-SEDENTARY COMMUNITIES research groups. Finally, we express our gratitude to the many colleagues who contributed with their data and advised us during the analysis.

$\therefore$

\section{References}

Alfaro C. 2002. Étoffes cordées du site néolithique de Tell Halula (Syrie - VIIIe millénaire avant J.-C.). Bulletin $d u$ CIETA 79: 17-25.

Andersson E. 2015. Textile Production at Birka. Household Needs or Organised Workshops? In Northern Archaeological Textiles: NESAT VII. Textile Symposium in Edinburgh, 5th-7th May 1999. 0xbow. Oxford: 44-50.

Anthony D. W. 2007. The Horse, the Wheel, and Language: How Bronze-Age Riders from the Eurasian Steppes Shaped the Modern World. Princeton University Press. Princeton.

Arbogast R., Jacomet S., Magny M. and Schibler J. 2006. The significance of climate fluctuations for lake level changes and shifts in subsistence economy during the Late Neolithic (4300-2400 cal B.C.) in Central Europe. Vegetation History and Archaeobotany 15: 403-418.

Barker G. 1985. Prehistoric farming in Europe. Cambridge University Press. Cambridge.

Baldia M. O., Frink D. S. and Boulanger M. T. 2008. The Earthen Long-Barrow of Džbán, Moravia, Czech Republic and its Implications for the Interaction between the Nordic Funnel Beaker and the Southern Baden Culture. In M. Furholt, M. Szmyt and A. Zastawny (eds.), The Baden Complex and the Outside World. Proceedings of the $12^{\text {th }}$ Annual Meeting of the EAA in Cracow 19-24th September, 2006. Studien zur Archäologie in Ostmitteleuropa 4. Bonn: 263-289.

Barber E. J. W. 1991. Prehistoric Textiles. The Development of Cloth in the Neolithic and Bronze Ages. Princeton University Press. Princeton.

Bartosiewicz L. 2007. Making a living: further technicalities. In A. Whittle (ed.), The Early Neolithic on the Great Hungarian Plain: investigations of the Körös culture site of Ecsegfalva 23, County Békés II. Varia Archaeologica Hungarica 21: 733-742.

Berger A., Loutre M. F. 2002. An Exceptionally Long Interglacial Ahead? Science 297: 1287.
Berglund B. 2003. Human impact and climate changessynchronous events and a causal link? Quaternary International 105: 7-12.

Berking J., Körper J., Wagner S., Cubasch U. and Schütt B. 2013. Heavy rainfalls in a desert(ed) city: A climate-archaeological case study from Sudan. Climate, Landscapes and Civilizations, Geophysical Monograph Series 198: 163-168.

Billamboz A., Köninger J. 2008. Dendroarchäologische Untersuchungen zur Besiedlungs- und Landschaftsentwicklung im Neolithikum des westlichen Bodenseegebietes. In W. Dörfler, J. Müller (eds.), Umwelt-Wirtschaft-Siedlungen im dritten vorchristlichen Jahrtausend Mitteleuropas und Südskandinaviens. Wachholz Verlag Neumünster. Kiel: 317-334.

Binford L. R. 1968. Archaeological perspectives. In S. R. Binford, L. R. Binford (eds.), New perspectives in archaeology. Aldine. Chicago: 5-32.

Bondár M. 2012. Prehistoric Wagon Models in the Carpathian Basin (3500-1500 BC). Archaeolingua. Budapest.

Bonfils C., de Noblet N., Guiot J. and Bartlein P. 2004. Some Mechanisms of mid-Holocene climate change in Europe, inferred from comparing PMIP models to data. Climate Dynamics 23: 79-98.

Braconnot P. and 19 co-authors 2007a. Results of PMIP2 coupled simulations of the Mid-Holocene and Last Glacial Maximum - Part 1: experiments and large-scale features. Climate of the Past 3: 261-277.

Braconnot P. and 19 co-authors. 2007b. Results of PMIP2 coupled simulations of the Mid-Holocene and Last Glacial Maximum - Part 2: feedbacks with emphasis on the location of the ITCZ and mid- and high latitudes heat budget. Climate of the Past 3: 279-296.

Brombacher C., Jacomet S. 1997. Ackerbau, Sammelwirtschaft und Umwelt: Ergebnisse archäobotanischer Untersuchungen. In J. Schibler, H. Huüster-Plogmann, S. Jacomet, C. Brombacher, E. Gross-Klee and A. Rast-Eicher (eds.), Ökonomie und Ökologie neolithischer und bron- 
zezeitlicher Ufersiedlungen am Zürichsee. Ergebnisse der Ausgrabungen Mozartstrasse, Kanalisationssanierungen Seefeld, AKAD/Pressehaus und Mythenschloss in Zürich. Monographien der Kantonsarchäologie Zürich vol. 20. Zürich: 220-279.

Burnham H. 1964. The World's Oldest Textiles. Meeting Place Journal of the Royal Ontario Museum 1: 105-108.

1965. Catal Hüyük - the Textiles and Twined Fabrics. Anatolian Studies 15: 169-174.

Bohnsack A. 1981. Spinnen und Weben. Entwicklung von Technik und Arbeit im Textilgewerbe. Rowohlt. Reinbek.

Budja M. 2015. Archaeology and rapid climate changes: from the collapse concept to a panarchy interpretative model. Documenta Praehistorica 42: 171-184.

Bulatović J. 2012. Exploitation of Domestic Animals in the Late Neolithic and Eneolithic in the Central Balkans. Case Studies: Vitkovo and Bubanj. Journal of Serbian Archaeological Society 28: 279-300.

Bulatović J., Milošević S. 2015. Animal Remains from the Mokranjske Stene-potkapina Site. In A. H. Kapuran, A. T. Bulatović (eds.), Mokranjske Stene, Kulturno nasleđe Negotinske Krjine. Muzej Krajine Negotin. Negotin: 41-55.

Chemikosova S. B., Pavlencheva N. V., Gur'yanov O. P. and Gorshkova T. A. 2006. The Effect of Soil Drought on the Phloem Fiber Development in Long-Fiber Flax. Fiziologiya Rastenii 53(5): 739-746.

Craig 0. E., Chapman J., Heron C., Willis L. H., Bartosiewicz L., Taylor G., Whittle A. and Collins M. 2005. Diary food production in Europe. Antiquity 79: 882-894.

Cummings V., Harris, 0. 2011. Animals, People and Places: The Continuity of Hunting and Gathering Practices across the Mesolithic-Neolithic Transition in Britain. European Journal of Archaeology 14(3): 361-382.

Cybulska M., Maik J. 2007. Archaeological textiles - a need of new methods of analysis and reconstruction. Fibres and Textiles in Eastern Europe 18(3): 100-105.

Charvát P. 2011. On Sheep, Sumerians and the Early State. In L. Vacín (ed.), U4du11-ga-nisá mu-ni-ib-du11. Ancient Near Eastern Studies in Memory of Blahoslav Hruška. Dresden: 49-60.

Chmielewski T., Gardyński L. 2010. New frames of archaeometrical description of spindle whorls: a case study of the late eneolithic spindle-whorls from the $1 \mathrm{C}$ site in Grödek, District of Hrubieszów, Poland. Archaeometry 52(5): 869-881.
Chantraine P. 2009. Dictionnaire étymologique de la langue grecque. Paris. Dictionnaire étymologique de la langue grecque: histoire des mots. Klinksieck. Paris.

Crewe L. 1998. Spindle Whorls. A study of form, function and decoration in prehistoric Bronze Age Cyprus. Paul Aström Förlag. Jonsered.

Čataj L. 2009. Josipovac Punitovački - Veliko Polje I. Eneolitičko, brončanodobno i srednjovjekovno naselje. (Eneolithic, Bronze Age and Medieval Settlement). Hrvatski Restauratorsi zavod. Zagreb.

Dash P. K. and 16 co-authors. 2014. Genome-wide analysis of drought induced gene expression changes in flax ( $\mathrm{Li}$ num usitatissimum). GM Crops \& Food 5(2): 106-119.

Davis B., Brewer S., Stevenson A. and Guiot J. 2003. The temperature of Europe during the Holocene reconstructed from pollen data. Quaternary Sciences Reviews 22 . 1701-1716.

De Capitani A., Deschler-Erb S., Leuzinger U., Marti-Grädel E. and Schibler E. 2002. Die jungsteinzeitliche Siedlung Arbon-Bleiche 3. Funde. Archäologie im Thurgau 11. Frauenfeld.

Evershed R. P. and 21 co-authors 2008. Earliest date for milk use in the Near East and southeastern Europe linked to cattle herding. Nature 455: 528-531.

Fábián Sz., Marton T. and Serlegi G. 2008. Késô rézkori település Abonyból (Turjányos-dúlő). In M. Gyöngyössy (ed.), Képek a múltból. Az elmúlt évek ásatásaiból Pest megyében. Szentendre: 24-25.

Fábián S. 2014. A badeni kultúra településtörténete a dél-balatoni régióban az újabb kutatási eredmények alapján. Unpublished $\mathrm{PhD}$ thesis. Eötvös Loránd University - Faculty of Humanities. Budapest.

Fábián Sz., Gábor S. and Daróczi-Szabó M. (in press). Begräbnis, Massengrab oder Opferstelle? Salzmünde - rule or exception? Proceedings of the Interdisciplinary Symposium $18^{\text {th }}-20^{\text {th }}$ of October in Halle, Saale, 2012.

Fabiš M. 2005. Pathological alteration of cattle skeletons, evidence for the draught exploitation of animals? In J. Davies, M. Fabiš, I. Mainland, M. Richards and R. Thomas (eds.), Diet and Health in Past Animal Populations: Current Research and Future Directions. Oxbow Books. Oxford: 58-62.

Fallah B., Sodoudi S. and Cubasch U. 2015. Westerly jet stream and past millennium climate change in Arid Central Asia simulated by COSMO-CLM. Theoretical and Applied Climatology. On line: http://link.springer.com/article/ 10.1007\%2Fs00704-015-1479-x\#/page-1 
Flückiger J., Monnin E., Stauer B., Schwander J., Stocker T. F., Chappellaz J., Raynaud D. and Barnola J. M. 2002. High resolution Holocene $\mathrm{N}_{2} \mathrm{O}$ ice core record and its relationship with $\mathrm{CH}_{4}$ and $\mathrm{CO}_{2}$. Global Biogeochem Cycles 16: 10-29.

Frangipane M., Andersson E., Nosch M. L., Laurito R., RastEicher A., Möller-Wiering S. and Wisti Lassen A. 2009. Arslantepe (Turkey): Textiles, Tools and Imprints of Fabrics from the $4^{\text {th }}$ to the $2^{\text {nd }}$ millennium BC. Paléorient 35: $5-30$.

Goosse H., Crespin E., Dubinkina S., Loutre M. F., Mann M. E., Renssen H., Sallaz-Damaz Y. and Shindell D. 2012. The Role of Forcing and internal Dynamics in explaining the "Medeival Climate Anomaly". Climate Dynamics 39: 2847-2866.

Gratten J., Wilson A. J., McRae A. F., Beraldi D., Visscher P. M., Pemberton J. M. and Slate J. 2008. A localized negative genetic correlation constrains microevolution of coat color in wild sheep. Science 319: 318-20.

Greif T. 1997. Prazgodovinska kolišča na Ljubljanskem barju. Arheološka interpretacija in poskus rekonstrukcije načina življenja / The prehistoric pile dwellings in the Ljubljansko barje. An archaeological interpretation and attempted reconstruction of the way of life. Arheo 18. Ljubljana.

Greenfield H. J. 1988. The Origins of Milk and Wool Production in the Old World. Current Anthropology 29: 573748.

2005. A Reconsideration of the Secondary Products Revolution in South-Eastern Europe. On the Origins and Use of Domestic Animals for Milk, Wool, and Traction in the Central Balkans". In J. Mulville, A. K. Outram (eds.), The Zooarchaeology of Fats, Oils, Milk and Dairying. Proceedings of the $9^{\text {th }}$ Conference of the International Council of Archaeozoology. Durham, August 2002. Oxbow Books. Oxford: 14-31.

Grömer K. 2005. Efficiency and technique - experiments with original spindle whorls (Leistung und Technik - Experimente zum Spinnen mit Originalspinwirteln). In P. Bichler, K. Grömer, R. Hofmann-de Keijzer, A. Kern and H. Reschreiter (eds.), "Hallstatt Textiles". Technical Analysis, Scientific Investigation and Experiment on Iron Age Textiles. British Archaeological Reports IS 1351. Archaeopress. Oxford: 107-116.

Grömer K., Kern D. 2010. Technical data and experiments on corded ware. Journal of Archaeological Science 37: 3136-3145.

Grömer K., Rösel-Mautendorfer H. and Bender Jørgensen L. 2013: Visions of Dress. Recreating Bronze Age Clothing from the Danube Region. Textile Journal of Cloth and Culture 11(3): 218-241.

Harris S. 2014. Flax fibre: Innovation and Change in the Early Neolithic. A Technological and Material Perspective. Textile Society of America Symposium Proceedings. Paper 913. On line: http://digitalcommons.unl. edu/tsaconf/ 913

Helbæk H. 1959. Notes on the Evolution and History of Linum. KUML: årbog for Jysk Arkaeologisk Selskab. Stiftsbogtrykkeri. Aarhus: 103-129.

1963. Tetxiles from Çatal Hüyük. Archaeology 67: 3946.

Halstead P., Isaakidou V. 2011. Revolutionary secondary products: the development and significance of milking, animal-traction and wool-gathering in later prehistoric Europe and the Near East. In T. Wilkinson, S. Sherratt and J. Bennet, J. (eds.), Interweaving Worlds: Systemic Interactions in Eurasia, $7^{\text {th }}$ to 1 st Millennia BC. Oxbow Books. Oxford: 61-76.

Herbig C., Maier U. 2011. Flax for oil or fibre? Morphometric analysis of flax seeds and new aspects of flax cultivation in Late Neolithic wetland settlements in southwest Germany. Vegetation History and Archaeobotany 20(6): 527-533.

Hochberg B. 1979. Spin, Span, Spun: Fact and folklore for Spinners. B. and B. Hochberg. Santa Cruz. California.

Hodder I. 1986. Reading the past: current approaches to interpretation in archaeology. Cambridge University Press. Cambridge.

Horváth L. A. 2001. Interpretationsmöglichkeiten der urzeitlichen Kultgruben (Archäologische und religionsgeschichtliche Analyse Aufgrund einer kupferzeitlichen Kultstätte) - Az őskori kultuszgödrök értelmezésének lehetôségei (Egy rézkori kultuszhely régészeti és vallástörténeti elemzése). MFMÉ-Studia Archaeologica 7: 43-89.

Horváth T. 2009. The intercultural connections of the Baden "culture". In G. Ilon (ed.), MSMO $\Sigma$ VI. Óskoros kutatók VI. Összejövetele. Szombathely: 101-149.

2010. Manifestation des Transcendenten in der Badener Siedlung von Balatonôszöd-Temetői dúlő - Kultgegenstände. Praehistorische Zeitschrift 85: 79-119.

2013 A Balatonószöd-Temetói dúló (M7/S10) lelóhely óskori településrészei. Digitális kiadás. Budapest.

Hurrell J. W. 1995. Decadal trends in the North Atlantic oscillation: Regional temperatures and precipitation. Science 269: 676-679. 
Hurrell J. W., Kushnir Y., Ottersen G. and Visbeck M. 2003. An overview of the North Atlantic Oscillation. Geophysical Monograph Series 134: 1-35.

Isaakidou V. 2006. Ploughing with cows: Knossos and the 'secondary products revolution'. In D. Serjeantson, D. Field (eds.), Animals in the Neolithic of Britain and Europe. Oxbow Books. Oxford: 95-112.

Jacomet S. 2009. Plant economies and village life in Neolithic lake dwellings at the time of the Alpine Iceman. $V e$ getation History and Archaeobotany 18: 47-59.

Johannsen N. 2005. Palaeopathology and Neolithic cattle traction: methodological issues and archaeological perspectives. In Davies, J., Fabis, M., Mainland, I., Richards, M. and Thomas, R. (eds.), Diet and Health in Past Animal Populations: Current Research and Future Directions. Oxbow Books. Oxford: 39-51.

Kalicz N. 2001. Die Protoboleráz-Phase an der Grenze von zwei Epochen. In P. Roman, S. Diamandi (eds.), Cernavodă III. - Boleráz - Ein vorgeschichtliches Phänomen zwischen dem Oberrhein und der unteren Donau. Symposium Mangalia/Neptun, 18-24. Oktober 1999. Studia Danubiana, ser. Symp. 2. Bucureşti: 385-435.

Kania K. 2015. Soft yarns, hard facts? Evaluating the results of a large scale hand-spinning experiment. Journal of Archaeological and Anthropological Sciences 7: 113130.

Kimbrough C. K. 2006. Spindle Whorls, Ethnoarchaeology and the Study of Textile Production in Third Millennium BCE Northern Mesopotamia: A Methodological Approach. Unpublished PhD thesis. York University Department of Anthropology. New York.

Kohler-Schneider M., Cannepele A. 2009. Late Neolithic agriculture in eastern Austria-archaeobotanical results from sites of the Baden and Jevišovice cultures (36002800 B.C.). Vegetation History and Archaeobotany 18: $61-74$.

Korošec P., Korošec J. 1969. Najdbe s koliščarskih naselbin pri Igu na Ljubljanskem barju / Fundgut der Pfahlbausiedlungen bei Ig am Laibacher Moor. Arheološki katalogi Slovenije 3. Narodni muzej. Ljubljana.

Kvavadze E., Bar-Yosef O., Belfer-Cohen A., Boaretto E., Jakeli N., Matskevich Z. and Meshveliani T. 2009. 30,000Year-Old Wild Flax Fibers. Science 325: 1359.

Laurito R., Lemorini C. and Perilli A. 2014. Making Textiles at Arslantepe, Turkey, in the $4^{\text {th }}$ and $3^{\text {rd }}$ Millennia BC. Archaeological Data and Experimental Archaeology. In C. Breniquet, C. Michel (eds.), Wool Economy in the Ancient Near East and the Aegean. Ancient Textile Series 17. Oxbow Books. Oxford: 151-168.
Leary J. 2014. Past Mobilities: Archaeological Approaches to Movement and Mobility. Ashgate. Burlington.

Leghissa E. 2015. Način okraševanja keramike ljubljanske kulture in pramenaste keramike - eksperimentalna arheologija. Arheološki vestnik 66: 275-292.

Leuzinger U., Rast-Eicher A. 2011. Flax processing in the Neolithic and Bronze Age pile-dwelling settlements of eastern Switzerland. Vegetation History and Archaeobotany 20(6): 535-542.

Loughran-Delahunt I. 1996. Functional analysis of Northwest coast spindle whorls. Western Washington University. Bellingham.

Magny M. 2004. Holocene climatic variability as reflected by mid-European lake-level fluctuations and its probable impact on prehistoric human settlements. Quaternary In ternational 113: 65-80.

Magny M., Peyron O., Sadori L., Ortu E., Zanchetta G., Vanniere B. and Tinner W. 2012. Contrasting Patterns of Precipitation Seasonality during the Holocene in the South and North-central Mediterranean. Journal of Quaternary Sciences 27: 494-502.

Magny M., Combourieu-Nebout N. 2013. Holocene changes in environment and climate in the central Mediterranean as reflected by lake and marine records. Climate of the Past 9: 1447-1454.

Maier U., Schlichtherle H. 2011. Flax cultivation and textile production in Neolithic wetland settlements on Lake Constance and in Upper Swabia (south-west Germany). Vegetation History and Archaeobotany 20(6): 567-578.

Maier U. 2001. Archäobotanische Untersuchungen in der neolithischen Ufersiedlung Hornstaad-Hörnle IA am Bodensee. In U. Maier, R. Vogt (eds.), Siedlungsarchäologie im Alpenvorland VI. Botanische und pedologische Untersuchungen zur Ufersiedlung Hornstaad-Hörnle IA. Forschungen und Berichte zur Vor-und Frühgeschichte in Baden-Württemberg 74: 9-384.

Maran J. 1998. Die Badener Kultur und der ägäisch-anatolische Bereich. Germania 76(2): 497-525.

Mårtensson L., Andersson E., Nosch M. L. and Batzer A. 2006. Technical report - Experimental archaeology Part 1, 2005-2006. Centre for Textile Research. Copenhagen. On line: http://ctr.hum.ku.dk/tools/Technical_re port_1_experimental_archaeology.pdf

Masson V., Cheddadi R., Braconnot P., Joussaume S., Texier D. and PMIP participants 1999. Mid-Holocene climate in Europe: what can we infer from PMIP model-data comparisons? Climate Dynamics 15: 163-182. 
Mauri A., Davis B., Collins P. and Kaplan J. 2014. The influence of atmospheric circulation on the mid-Holocene climate of Europe: a data-model comparison. Climate of the Past 10: 1925-1938.

Mayewski P. A. and 15 co-authors. 2004. Holocene Climate Variability. Quaternary Research 62: 243-255.

Mazăre P. 2014. Investigating Neolithic and Copper Age Textile Production in Transylvania (Romania). Applied Methods and Results. In M. Harlow, C. Michel and M. L. Nosch, (eds.), Prehistoric, Ancient Near Eastern and Aegean Textiles and Dress. An interdisciplinary anthology. Oxbow Books. Oxford and Philadelphia: 1-42.

Médard F. 2006. Les activités de filage sur les sites néolithiques du plateau suisse. Système technique de production du fil dans son contexte économique et social. Monographies du Centre de Recherches Archéologiques 28. Paris.

2010. L'art du tissage au néolithique: IVe-IIIe millénaires avant J.-C. en Suisse. Le Centre national de la recherche scientifique. Paris.

2012. Switzerland: Neolithic Period. In M. Gleba, U. Mannering (eds.), Textiles \& textile production in Europe: From Prehistory to $A D$ 400, Vol. 11. Oxbow Books. 0xford: 367-377.

McCorriston J. 1997. The fiber revolution: textile extensification, alienation, and social stratification in ancient Mesopotamia. Current Anthropology 38: 517-49.

Pajagič-Bregar G., Velušček A., Tolar T., Strlič M., Bukošek V., Kolar J. and Ravbar I. 2009. Raziskave in konserviranje preje z Ljubljanskega barja / Analysis and conservation of the Ljubljansko barje yarn. In A. Velušček (ed.), Koliščar ska naselbina Stare gmajne in njen čas. Ljubljansko barje v 2. polovici 4. tisočletja pr. Kr. / Stare gmajne PileDwelling Settlement and its era. The Ljubljansko barje in the $2^{\text {nd }}$ half of the $4^{\text {th }}$ millennium BC. Opera Instituti Archaeologici Sloveniae 16. ZRC SAZU Publishing. Ljubljana: 309-318.

Petrova V. N. 2011. Textile Production in the Bronze and Early Iron Age in the North Balkan Region. Unpublished $\mathrm{PhD}$ thesis. Sofia University. Sofia.

Peyron O., Magny M., Goring S., Joannin S., de Beaulieu J. L., Brugiapaglia E., Sadori L., Garfi G., Kouli K., Ioakim C. and Combourieu-Nebout N. 2013. Contrasting patterns of climatic changes during the Holocene across the Italian Peninsula reconstructed from pollen data. Climate of the Past 9: 1233-1252.

Pipes M.-L., Kruk J. and Milisauskas S. 2014. Assessing the archaeological data for wool-bearing sheep during the middle to late Neolithic at Bronocice, Poland. In H. J.
Greenfield (ed.), Animal Secondary Products: Domestic Animal Exploitation in Prehistoric Europe, the Near East and the Far East. 0xbow Books. Oxford: 80-102.

Raczky P. 1995. New data on the absolute chronology of the Copper Age in the Carpathian Basin. In T. Kovács (ed.), Neuere Daten zur Siedlungsgeschichte und Chronologie der Kupferzeit des Karpatenbeckens. Magyar Nemzeti Múzeum. Budapest: 51-60.

Rast-Eicher A. 2005. Bast before Wool: the first textiles. In P. Bichler, K. Grömer, R. Hofmann-de Keijzer, A. Kern and H. Reschreiter (eds.), "Hallstatt Textiles". Technical Analysis, Scientific Investigation and Experiment on Iron Age Textiles. British Archaeological Reports IS 1351. Archaeopress. Oxford: 117-131.

Rast-Eicher A., Bender Jørgensen L. 2013. Sheep wool in Bronze Age and Iron Age Europe. Journal of Archaeological Science 40: 1224-1241.

Rast-Eicher A. 2014. Bronze and Iron Age Wools in Europe. In C. Breniquet, C. Michel (eds.), Wool Economy in the Ancient Near East and the Aegean. Ancient Textile Series vol. 17. Oxbow Books. Oxford: 12-21.

Reed K. 2016. Agricultural change in Copper Age Croatia (ca. 4500-2500 cal B.C)? Archaeological and Anthropological Sciences. doi: 10.1007/s12520-016-0330-3.

Riede F. 2014. Climate Models: Use archaeology record. Nature 513: 315.

Roeckner E., Arpe K., Bengtsson L., Christoph M., Claussen M., Dumenil L., Esch M., Giorgetta M., Schlese U. and Schulzweida U. 1996. The atmospheric general circulation model ECHAM4: model description and simulation of present-day climate. Technical Report. Max Planck Institut fr Meteorologie. Hamburg.

Rooijakkers C. T. 2012. Spinning Animal Fibres at Late Neolithic Tell Sabi Abyad, Syria? Paléorient 38: 93-103.

Russo E., Cubasch U. 2016. Mid-to-late Holocene Temperature Evolution and Atmospheric Dynamics over Europe in Regional Model Simulations. Climate of the Past 12: 1645-1662.

Ryder M. L. 1964. The history of Sheep Breeds in Britain. Agricultural History Review 12: 1-12; 65-82.

1974. Wools from Antiquity. Textile History 5: 100-110.

1982. Sheep - Hilzheimer 45 years on. Antiquity 56 : 15-23.

1990a. Skin, and wool-textile remains from Hallstatt, Austria. Oxford Journal of Archaeology 9(1): 37-49. 
1990b. Wool remains from Scythian burials in Siberia. Oxford Journal of Archaeology 9(3): 313-321.

1992. Iron Age, haired, animal skins from Hallstatt, Austria. Oxford Journal of Archaeology 11(1): 55-67.

Schibler J., Jacomet S., Hüster-Plogmann H. and Brombacher C. 1997. Economic crash in the 37th and 36th centuries cal. BC in Neolithic lake shore sites in Switzerland. Anthropozoologica 25: 553-570.

Schick T. 1988. Nahal Hemar Cave: Cordage, Basketry and Fabrics. Atiqot 18: 31-43.

Schlichtherle H. 2009. Eine neue Siedlungskammer im westlichen Federseeriedund, ihre Bedeutung für das Verständnis neolithischer Siedelsysteme. In J. Biel, J. Heiligmann and D. Krausse (eds.), Landesarchäologie. Festschrift für Dieter Planck zum 65. Geburtstag. Forschungen und Berichte zur Vor- und Frühgeschichte in BadenWürttemberg 64. Theiss. Stuttgart: 61-86.

Schlichtherle H., Bleicher N., Dufraisse A., Kieselbach P., Maier U., Schmidt E., Stephan E. and Vogt R. 2010. Bad Buchau - Torwiesen II: Baustrukturen und Siedlungsabfälle als Indizien der Sozialstruktur und Wirtschaftsweise einer endneolithischen Siedlung am Federsee. In E. Claßen, T. Doppler and B. Ramminger (eds.), Familie - Verwandtschaft - Sozialstrukturen: Sozialarchäologische Forschungen zu neolithischen Befunden. Fokus Jungsteinzeit. Berichte der AG - Neolithikum 1. Kerpen, Loogh: 157-178.

Sherratt A. G. 1981. Plough and pastoralism: aspects of the secondary products revolution. In I. Hodder, G. Isaac and N. Hammond (eds.), Pattern of the Past: Studies in honour of David Clarke. Cambridge University Press. Cambridge: 261-305.

1997. Economy and Society in Prehistoric Europe: Changing Perspectives. Edinburgh University Press. Edinburgh.

2006. La traction animale et la transformation de l'Europe néolithique. In P. Pétrequin, R.-M. Arbogast, A.-M. Pétrequin, S. van Willigen and M. Bailly (eds.), Premiers chariots, premiers araires. La diffusion de la traction animale en Europe pendant les IVe et IIIe millénaires avant notre ère. Monograph du Centre de Recherches Archéologiques 29. Paris: 329-360.

Shishlina N. I., Orfinskaya O. V. and Golikov V. P. 2003. Bronze Age Textiles from North Caucasus: new evidence of fourth millennium BC fibers and fabrics. Oxford Journal of Archaeology 22(4): 331-344.

Solanki S. K., Usoskin I. G., Kromer B. and Schüssler Beer J. 2004. Unusual Activity of the Sun during recent decades compared to the previous 11000 years. Nature 431 : $1084-1087$.

Stadler P., Draxler S., Friesinger H., Kutschera W., Priller A., Rom W., Steirer P. and Wild E. M. 2001. Absolute chronology for early civilizations in Austria and Central Europe using ${ }^{14} \mathrm{C}$ dating with accelerator mass spectrometry with special results for the absolute chronology of the Baden culture. In P. Roman, S. Diamandi (eds.), Cernavodă III. - Boleráz - Ein vorgeschichtliches Phänomen zwischen dem Oberrhein und der unteren Donau. Symposium Mangalia/Neptun, 18-24. Oktober 1999. Studia Danubiana, ser. Symp. 2. Bucureşti: 541-562.

Struhár V., Soják M. and Cheben I.2014. The Baden culture hilltop settlements in Northern Slovakia and their "Socio-symbolic" importance. In A. Zastawny (ed.), The Baden culture around the western Carpathians. Via archaeologica. Kraków: 237-272.

Styring A., Maier U., Stephan E., Schlichtherle H. and Bogaard A. 2016. Cultivation of choice: new insights into farming practices at Neolithic lakeshore sites. Antiquity 90: 95-110.

Šavel I. 2009. Pod Kotom - jug pri Krogu I/II. Arheologija na avtocestah Slovenije. Zavod za varstvo kulturne dediščine Slovenije. Ljubljana.

Tolar T., Velušček A. 2009. Discovery of flax (Linum usitatissimum) at Ljubljansko barje, Slovenia. Histria Antiqua 18: 187-194.

Tolar T., Jacomet S., Velušček A. and Čufar K. 2011. Plant economy at a late Neolithic lake dwelling site in Slovenia at the time of the Alpine Iceman. Vegetation History and Archaeobotany 20: 207-222.

Tóth M., Magyari E. K., Buczkó K., Braun M., Panagiotopoulos K. and Heiri 0. 2015. Chironomid-inferred Holocene temperature changes in the South Carpathians. The Holocene 25(4): 569-582.

Wagner S., Widmann M., Jones J., Haberzettl T., Lücke A., Mayr C., Ohlendorf C., Schäbitz F., Zolitschka B. 2007. Transient simulations, empirical reconstructions and forcing mechanisms for the mid-holocene hydrological climate in Southern Patagonia. Climate Dynamics 29: 333-355.

Wanner H., Solomina 0., Grosjean M., Ritz S. P. and Jetel M. 2011. Structure and origin of Holocene cold events. Quaternary Science Reviews 30: 3109-3123.

Weninger B. and 18 co-authors 2009. The Impact of Rapid Climate Change on prehistoric societies during the Holocene in the Eastern Mediterranean. Documenta Praehistorica 36: 551-583. 
Weninger B., Harper T. 2015. The Geographic Corridor for Rapid Climate Change in Southeast Europe and Ukraine. In E. Schultze (ed.), Neolithic and Copper age between the Carpathians and the Aegean. Archeologie in Eurasien 31. Deutsches Archäologisches Institut. Berlin: 475-505.

Wolff J., Maier-Reimer E. and Legutke S. 1997. The Hamburg Primitive Equation Model HOPE. Technical Report. German Climate Computer Service. Hamburg.

Verhecken A. 2010. The moment of inertia: a parameter for the functional classification of worldwide spindlewhorls. In E. Andersson Strand, M. Gleba, U. Mannering, C. Munkholt and M. Ringgaard (eds.), North European symposium for archaeological textiles $X$. Oxbow Books. Oxford - Oakville: 257-270.

Vakirtzi S., Koukouli-Chrysanthaki C. and Papadopoulos S. 2014. Spindle whorls from two prehistoric sites on Thassos. In M. Harlow, C. Michel and M. L. Nosch (eds.), Prehistoric, Ancient Near Eastern and Aegean Textiles and Dress. An interdisciplinary anthology. Oxbow Books. Oxford - Philadelphia: 43-57.
Vigne J. D., Helmer D. 2007. Was milk a "secondary product" in the old world Neolithization process? Its role in the domestication of cattle, sheep and goats. Anthropozoologica. 42 (2): 9-40.

Vila E., Helmer D. 2014. The Expansion of Sheep Herding and the Development of Wool Production in the Ancient Near East: An Archaeozoological and Iconographical Approach. In C. Breniquet, C. Michel (eds.), Wool Economy in the Ancient Near East and the Aegean, Ancient Textile Series vol. 17. Oxbow Books. Oxford: 22-40.

Von Storch H., Zorita E., Jones J., Dimitriev Y., GonzalezRouco F. and Tett S. 2004. Reconstructing Past Climate from Noisy Data. Science 306: 679-682.

Vosteen M. 1996. Unter die Räder gekommen. Untersuchungen zu Sherratts 'Secondary Products Revolution'. Archäologische Berichte 7. Deutsche Gesellschaft für Urund Frühgeschichte. Habelt. Bonn.

Zohary D. 1996. The mode of domestication of the founder crops of Southwest Asian agriculture. In D. Harris (ed.), The Origins and Spread of Agriculture and Pastoralism in Eurasia. University College London Press. London: 142-158. 